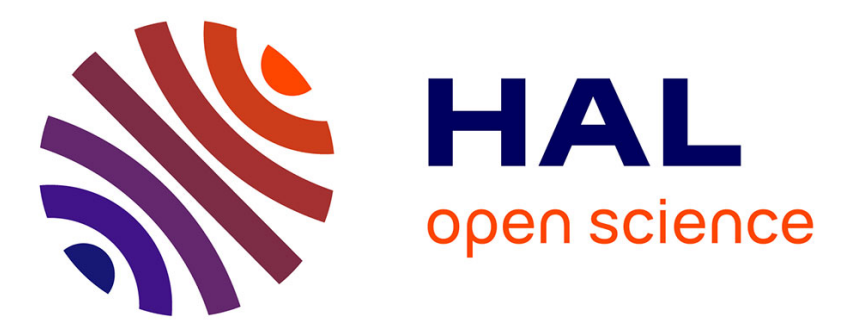

\title{
Worldwide IP coverage of patented inventions in large pharma firms: to what extent do the internationalisation of R\&D and firm strategy matter?
}

\author{
Patricia Laurens, Christian Le Bas, Antoine Schoen
}

\section{- To cite this version:}

Patricia Laurens, Christian Le Bas, Antoine Schoen. Worldwide IP coverage of patented inventions in large pharma firms: to what extent do the internationalisation of $\mathrm{R} \& \mathrm{D}$ and firm strategy matter?. International Journal of Technology Management, 2019, 80 (3/4), pp.177-211. 10.1504/IJTM.2019.100283 . hal-01725229

\author{
HAL Id: hal-01725229 \\ https://hal.science/hal-01725229
}

Submitted on 7 Mar 2018

HAL is a multi-disciplinary open access archive for the deposit and dissemination of scientific research documents, whether they are published or not. The documents may come from teaching and research institutions in France or abroad, or from public or private research centers.
L'archive ouverte pluridisciplinaire HAL, est destinée au dépôt et à la diffusion de documents scientifiques de niveau recherche, publiés ou non, émanant des établissements d'enseignement et de recherche français ou étrangers, des laboratoires publics ou privés. 
Worldwide IP coverage of patented inventions in large pharma firms: to what extent do the internationalisation of R\&D and firm strategy matter?

\author{
Patricia Laurens \\ Université Paris Est, CNRS, LISIS, IFRIS, \\ 2, bd Blaise Pascal, 93160 Noisy le Grand, France \\ Email: patricia.laurens@esiee.fr \\ Christian Le Bas* \\ ESDES - Business School of UCLy, \\ 10, Place des Archives, 69002 Lyon, France \\ Email: clebas@univ-catholyon.fr \\ *Corresponding author \\ Antoine Schoen \\ Université Paris Est, IFRIS, LISIS, ESIEE, \\ 2, bd Blaise Pascal, 93160 Noisy le Grand, France \\ Email: a.schoen@esiee.fr
}

\begin{abstract}
.
The paper deals with the determinants of worldwide IP coverage of patented inventions in large pharmaceutical firms. We support the core idea that the internationalisation of firm $\mathrm{R} \& \mathrm{D}$ and an economic presence in a foreign country are positive key factors which explains global IP coverage. For the global pharmaceutical industry, we estimate probit models on the probability that a patent will be expanded worldwide. We retain two categories of worldwide patent: the well-known triadic patent and the new triadic one (triadic + China + Korea). The data set encompasses the 17,633 priority patents applied for by 76 enterprises from several countries over the period 2003-2005. One important finding is that patenting in Japan sets up an important barrier, giving Japanese firms an advantage when triadic patenting is considered. For European and US firms, our estimation results confirm the idea that the level of firm $\mathrm{R} \& \mathrm{D}$ internationalisation is a significant explanatory factor in international IP coverage, together with control variables. We highlight an inverted U-shaped relationship between these two variables. The hypothesis related to a firm economic presence is also verified.
\end{abstract}

Key word: global patent coverage, pharma firms, internationalisation of $R \& D$, strategy, globalisation of technology

JEL code: F23, F60, L65, O34

1. Introduction and motivation: Scale and determinants of worldwide IP coverage and technology internationalisation

One particular important advantage of the patent system is to authorise the possible worldwide extension of the protection of an invention patented in the country of origin. 
Thanks to the Paris Convention (1883) this process is becoming legal. The decision to extend protection abroad is now well documented (Baudry et al., 2006; Maskus, 2000; Park, 2008). The scale and the motives of worldwide patent coverage have been a significant topic that has long been investigated (among others: Lanjouw et al., 1998). Extending patents to different countries after obtaining a priority patent is an important phenomenon from a firm economic performance perspective. In the globalised economic world firms, often, but not only, large, have to sell their products on several foreign markets in order to amortise the costs of tangible and intangible investments. When new products are at stake it appears crucial to patent in foreign countries in order to be sure innovative firms keep their capacity to take and maintain durable advantages over their competitors. As a consequence, worldwide IP coverage of inventions is an important element of firm growth and sets up a strategic challenge for firms (presumably large) to protect their rents stemming from innovations.

The internationalisation of technology and innovation activity matches an important trend that is potentially important for the extension of worldwide patenting. This takes many pictures. Twenty years ago, Archibugi and Michie (1997) suggested dealing with the global generation of technology separately from the global exploitation of technology. The first is mainly related to the level of internationalised firm R\&D activity (see the framework constructed by Dunning, 1997; Kuemmerle, 1997; Lall, 1979, Rugman, 1981). Its scale depends on countries, sectors, and firm size (see the evidence gathered by Patel and Vega, 1999; Le Bas and Sierra, 2002).

The international exploitation of technology has two important features: a) international transactions on the market for technology (licensing) and b) the sales of new products (or old products manufactured by the new production process) on foreign markets. The latter are much more well-known and are largely driven by the forces of international trade. Nevertheless, an important point that should be emphasised strongly here is that the firms have to protect their inventions legally, through patenting on foreign markets, in order to increase value from their technologies (Archibugi and Michie, 1997). As a consequence, the internationalisation of patenting activity is related to technology internationalisation. In our study we focus on the process of the global generation of technology and consider one of its main aspects: the process of $R \& D$ internationalisation. This topic has been extensively investigated in the literature (see among others: Dunning and Lundan, 2009, MoncadoPaternò-Castello, 2011; Narula and Zanfei, 2005; OECD, 2005; Patel and Pavitt, 1991; UNCTAD, 2005). The drivers and consequences of the internationalisation of corporate invention have attracted particular attention (Frost, 2001; Ambos, 2005; Abramosvsky et al. 2008; Sachwald, 2008). One important issue is to know if R\&D activity is increasingly internationalised (Cantwel, 1995; Moncada-Paternò-Castello et al., 2011). At the turn of the century, studies concluded that there was an increasing internationalisation movement but underlined the rather limited levels of internationalisation (Patel \& Vega 1999, Roberts 2001, Le Bas \& Sierra 2002, UNCTAD 2005, Doz et al., 2006). By contrast the recent papers by Laurens et al. (2015a, 2015b) clearly envisage a possible R\&D deglobalisation for European MNCs between 1994 and 2005. The interpretation is that managerial focus is shifting towards the organisational consolidation of the existing complex international R\&D structures, in line with Gammeltoft's (2006) analysis. These provide relevance for works which note the importance of factors in favour of home country centralisation (Almeida, 1996; Bjorvatn and Eckel, 2006; Branstetter, 2006). The increasing significance of transaction costs when R\&D 
internationalisation is intensified was also recently pointed out by Iammarino and McCann (2013). Many arguments have been put forward regarding the motives for investing in R\&D activity abroad (see among others Barlett and Ghoshal, 1989; Piscitello, 2011). An important framework relating to the motivations for locating $\mathrm{R} \& \mathrm{D}$ abroad is based on the important contributions by Dunning (1997), Kuemmerle (1997), Ronstadt (1978) and Rugman (1981). In summary, the two main reasons why firms internationalise their technological activities are: 1) the necessary adaptation of products and processes to foreign conditions, a compulsory rule for penetrating markets abroad; and 2) the acquisition of knowledge and expertise from foreign R\&D centres and universities. An important summarised picture was provided by Kummerle (1997), noting that a firm goes abroad to augment the firm's capabilities, and not only to exploit further existing capabilities. This perspective has been developed in empirical studies that have all convincingly shown that the dominant strategy as far as location abroad is concerned was of the Home Base Augmenting (HBA) type and not the Home Base Exploiting (HBE) type (Patel \& Vega 1999, Le Bas \& Sierra 2002). In these two dominant options MNCs have relative advantages at home: HBA strategies characterise locations that have complementary strengths to those created at home, HBE strategies consist in exploiting abroad the advantage created at home.

In this article we analyse IP internationalisation (IPI in short) as related to technology internationalisation (TI) and firm strategy. We consider the sector of the pharmaceutical industry where IP rights are of particular importance as the provider of the empirical material for this study. The ideas are developed as follows. The next section presents a literature survey, the research question and our main hypotheses. Section 3 portrays the global pharmaceutical sector as the context of the study, the data set and the firm sample. Section 4 is related to the modelling, the variables we have built up, and the econometric strategy. Section 5 provides information on our estimations and results.

\section{Literature survey, research question and main hypotheses}

The factors explaining why firms and, more specifically, MNCs, protect their patented inventions abroad and for the most part in large economies have received little attention in the literature. The intrinsic economic value of patented invention crucially affects the decision to patent internationally (Chan, 2010). Moreover, in the last few decades the socalled TRIPs agreement has pushed countries wishing to access global markets to strengthen their IP regimes to reach a level similar to the standard implemented in developed countries (Bosworth, 2006). As a consequence, the dynamic underlying TRIPs sets up an important institutional driver of the growth of IP. Despite the harmonisation of patenting laws across countries the strength of the IPR regime establishes an important element. A firm will be reluctant to extend its patents in foreign countries where it cannot defend its rights in court (Allred and Park, 2007). The importance of patent enforcement is noted by Chan (2010) for agricultural biotechnology inventions. Differences in filing costs play a significant role as well because this influences earnings from an international patenting (Chan, 2010). As regards international IP coverage, product competition matters (Huang and Jacob, 2014). In effect it has recently been noted that patenting is strongly correlated to the firm's capacity to maintain a certain market power (Fisher III and Oberholzer-Gee, 2013). We must also bear in mind that strategic motives (for example blocking competitors) may also play a role. 
Nevertheless, the process of IPI cannot be explained by the sole wish to maintain the firm's freedom to operate its products or its market power on international product markets. As this process is costly, a firm also expects to compensate such costs by licensing its new technology and/or by increasing its market share abroad, thanks to its innovative products and its market power. Surprisingly no study envisages the decision to patent the same invention in a set of countries in relation to the international position of the firm. To our knowledge, the only exception is the work by Chan (2010), which shows that international trade positively affects the decision to patent internationally. The issue we want to address is whether the degree and scope of the firm's R\&D internationalisation (we also use the term Technology internationalisation, or TI) has an impact on the scale of firm IPI coverage. In order to monitor IPI coverage, one could rely on international applications using the PCT (Patent Cooperation Treaty) procedure, or follow the geographical extensions of a priority application in a selection of countries. In this latter strand, the OECD has set up patent indicators based on triadic patent families, i.e. patents filed at the EPO (European Patent Office), JPO (Japanese Patent Office) and USPTO (United States Patent and Trademark Office), which share one or more priorities (Dernis and Khan, 2004). These families are built to filter a set of patents covering a more homogeneous set of inventions (getting rid of the patent office bias), and the most important inventions (at least those applied for in the world's largest markets). Reducing the home country advantage, triadic families are used to produce indicators for international comparisons (OECD, 2016, de Rassenfosse, 2009). However, the choice of selecting only Triad countries has also raised doubts. It is increasingly argued that the fast-growing Asian countries, in particular China but also Korea, should be taken into consideration in order to include the shift in patenting in these countries (Sternitzke, 2009).

We share these views and will rely on both the IP extension in the Triad countries and in the Triad, plus the China and Korea zone (Extended Triad) as indicators of IP coverage. In this paper we construct our empirical analysis through the use of triadic patenting. As a consequence, when we talk about IPI or international patenting we have in mind intercontinental protection as measured by triadic and new triadic ${ }^{1}$ patenting.

Our research question is related to the following idea: we observe a gap between, on the one hand, an emphasis on the scale of R\&D globalisation and, on the other hand, the fact that only a few studies address this process as a potential driver of international IP coverage (knowing other factors determines the process of international IP coverage). We want to fill this gap by investigating the relation between international production of R\&D activity and international protection of patented inventions. Our perspective is that the more a firm has internationalised its production of inventions, the more it is prone to patent activity in many countries, and thus has also internationalised its IP activity. That is the main relationship we would like to study. Consequently, we assume that R\&D internationalisation may be a driver of patenting international coverage. This idea is supported by the following view: strong IPR protection is a positive determinant of technology investments and the attractiveness of $R \& D$ facilities (Narula \& Guimón, 2010; Saggi, 2002). Moreover, strong IPR regimes are likely to stimulate local patenting because MNCs are interested in protecting new knowledge produced locally, as knowledge transferred from the home country. To put it simply in this context, firms invest in $\mathrm{R} \& \mathrm{D}$ abroad then patent their inventions that are produced locally

\footnotetext{
${ }^{1}$ That is to say triadic plus China and Korea.
} 
and extend patent protection abroad to obtain more economic value through sales of new products or the licensing of new processes. Of course, when the IP regime is less strong the story is a little different. In countries in which IP regimes are rather weak if the market is large there is considerable evidence that location close to customers is an important motive for the internationalisation of $R \& D$. China provides the best example of this trend. For this country empirical evidence shows MNCs patents increasing (Chen, 2008).

Our main hypotheses stem from the literature and from prior empirical study of our data set. When a firm that we presume to be multinational conducts R\&D activity abroad it has to protect its inventions found in different countries by appropriate patent protection. The more a firm is involved in R\&D activity in foreign countries, the more it has to extend its national protection in these countries. Firm motivation aims to prevent the process of knowledge leaking out through knowledge workers' mobility, and more generally from imitation by its competitors $^{2}$. Consequently, our central hypothesis is:

Hypothesis 1 . The more a firm is internationalised in terms of $R \& D$, the higher will be the probability that it applies a triadic or new triadic patent.

We cannot exclude the process of IPI meets a threshold, a level after which IPI is reversed while $R \& D$ internationalisation is still increased. The literature says nothing about this phenomenon. Nevertheless it is possible to put forth the following idea of a life cycle if IP supporting such a trend. When a firm begins to internationalise its R\&D activity, it patents its own R\&D internationally a lot. As a consequence IT and IPI are growing together. Because triadic (and more generally international) patenting is costly, the firm learns step by step, in order to manage its patent behaviour more effectively. In this context it is obvious a firm continuing to internationalise its $\mathrm{R} \& \mathrm{D}$ should patent less abroad because it patents more efficiently. With this perspective we can expect an inverted $U$ shape relationship between R\&D internationalisation and firm level of IPI. In our tentative interpretation we consider the timing of firm R\&D internationalisation as a possible relevant important factor. This analyse drives us to build a secondary option to Hypothesis 1, Hypothesis 1bis:

Hypothesis 1bis: The triadic and new triadic patenting varies with firm $R \& D$ internationalisation level according to an inverted $\mathrm{U}$ shape relationship

Of course we will estimate different models in order to check which option is the more relevant.

We are aware that TI cannot alone trigger IPI. Other factors matter, in particular the firm strategy in terms of market protection of its new products. A firm has an interest in protecting its market share by patenting abroad. The international extension of patent protection is a behaviour that can be explained by a simple model of costs/advantages. Indeed, expanding protection obtained in one particular country in other countries is costly. The level of costs depends on the country's regulation and on the duration of the protection. Besides application and maintenance fees, additional costs emerge for enforcing patent rights in various

\footnotetext{
2 Internationalisation in general equally plays a role. For example, according to Blind et al. (2003) pharmaceuticals are more internationally oriented - and, therefore, have a higher average number of family members - than for example machinery or automobiles.
} 
countries. As a consequence, a firm has to be sure to benefit from protection through its product's commercial success or the protection due to the new technological process it uses. As stated by Neuhausler and Frietsch (2013): “... an application for a patent in a foreign country means that the applicant tries to secure that market to sell his invention and is willing to bear additional costs for the protection of his invention in the respective market. In this sense, it is assumed that a patentee only files a patent abroad if he expects a corresponding profit from the sale of the protected technology". This comes as an important hypothesis:

Hypothesis 2. When a firm has a commercial or an economic activity in a country it increases the probability of applying for a patent in that country.

3. Context of the study, data set and sample analysis

Our study is conducted on the pharmaceutical industry, where securing returns on $R \& D$ investment is central to firms' business models in Pharmaceuticals (WIPO, 2015: 27).

\subsection{The pharmaceutical sector}

Since the 1990s and the start of the "biotechnology revolution", the pharma industry has undergone huge changes (Malerba and Orsenigo, 2015). The need for new knowledge has opened the way for newcomers, the biotech firms (often start-ups, spin-offs from US universities) in an industry dominated for decades by an oligopolistic core of large firms in Europe (Switzerland, the United Kingdom and Germany), and the US. It has resulted in "a division of labour with the biotech firms and publicly funded laboratories focusing on basic $\mathrm{R} \& \mathrm{D}$ and big pharma buying chemical compounds from the biotech firms and bringing a few of them to market after long and costly steps of clinical trials and marketing campaigns" (Mazzucato and Dosi, 2010) However, despite the promises of molecular biology and the huge amount of money spent on $\mathrm{R} \& \mathrm{D}$ by firms in this new field of research, the "productivity" of pharmaceuticals declined and far fewer new drugs were produced. At the same time, a worldwide strengthening of drug regulations and regulation of drug prices in many countries facing increasing healthcare needs (Japan, France, Italy...) put additional pressure on the pharmaceutical industry. Firms' innovative strategies to adapt were various and depended both on factors internal to the firm (history, knowledge-absorbing capacity, location, internal organisation) and factors related to their national innovation system. With huge public R\&D investments to develop biotech competences, strong IP protection, an efficient funding system (mainly through the NIH), the presence of venture capital and a well-integrated innovation system, the US took the lead in the molecular biology revolution. Consequently, US pharma firms and public laboratories have attracted foreign FDI and acquisitions from most of the big European pharma firms. Novartis delocalised its global research headquarters in Cambridge (US) in 2002 and bought Chiron, a US biotech company, in 2006. In 2007 Roche acquired several US biotech companies (454 Life Science, Bio Veris, ...), and Astra Zeneca bought MedImmune (US). In Europe, responses varied depending on the country, but generally speaking there was a trend in the growth of firm size through 
international mergers and acquisitions (M\&A): Swiss firms massively internationalised worldwide, Hoechst-AG was acquired by Rhone-Poulenc Rorer, Knoll (BASF Pharma) by Abbott in 2000, .... Japanese firms lagged behind and remained mostly focused on their domestic market (the second largest market in the world). This resulted in "two types of firms with distinct technological competencies and competitive strategies: a core of big pharma generating new drugs and a group of imitators that rely on incremental imitations, taking licences from the core group or manufacturing generic drugs" ${ }^{3}$. (Bottazzi et al., 2001). While the latter group rely on the protected domestic market or, in countries with drug price controls or low IP protection (low incentives for innovation), with me-too drugs, (huge markets such as the market of generic drugs), the former group of firms rationalised their resources, established networks with external partners, appropriated external knowledge and resources through acquisitions or collaborations with biotech firms or public laboratories, and increased their rate of M\&A to strengthen and expand their markets. If large firms used to locate their first R\&D centres near their headquarters, they internationalised the most recent centres in rich and knowledge-rich countries in biotech regions (most often in the US but also in nearer European biotech clusters in the UK, Switzerland, France) and developed facilities in countries with a high demand for drugs (France, Germany). Finally, there has been evidence of a trend in the internationalisation of pharma $R \& D$ laboratories in emerging countries such as China, Singapore and India since the mid-1990s: Sanofi, Glaxo or Pfizer have built R\&D facilities in India; in China, many Chinese pharma are joint ventures with big western pharma (Roche SH, J\&J SH, Xian-Janssen (J\&J), Lederle SH (Wyeth) ...

Globalisation was mandatory for big pharma to rationalise their resources and to access new markets in developing countries. The level of overall pharma R\&D internationalisation can be estimated from foreign FDI: $20 \%$ to $70 \%$ of pharma R\&D investments are spent in foreign countries (Gassmann et al., 2008). In 2007, the pharmaceutical industry generated 16.4 bn EUR PPS inward BERD worldwide (Dachs et al. 2012). Besides access to the best basic sciences in biotech regions, potential new drugs underwent a long process of clinical trials, more easily carried out at lower cost in large emerging countries (India, China). The need to consider patients' genetic particularities also pushes for internationalisation in the drug development process. Finally, drug manufacturing was also globalised but a trade-off between drug production at low cost and sufficient IP protection to avoid imitation had to be considered. To conclude, internationalisation in the pharma industry was a mandatory strategy to face and adapt to the new stresses, to access global markets and prepare for the future. The core of the pharma industry, the big pharmas in western countries, were the first movers ${ }^{4}$. They initiated an abundant wave of internationalisation in the early 1990s and at the turn of the century had become global players, acting "as nodal players with multiple partnerships with a variety of companies" (Roijakkers and Hagedoorn, 2006) or as "network integrators, rather than a prime locus of discovery" (Raffols et al., 2104). In contrast, most of the largest Japanese pharma companies have remained centred on their domestic market. However, in order to confront (new) foreign competition in their opening domestic market,

\footnotetext{
${ }^{3}$ The two strategies could be found in a single firm that can adopt different strategies according to the product.

${ }^{4}$ In 2004, the first twelve pharmaceutical firms with the highest turnover were all located in western countries: Pfizer (USA), GlaxoSmithKline (G.B.), Sanofi-Aventis (France), Johnson \& Johnson (USA), Merck \& Co (USA), Novartis (Switzerland), AstraZeneca (G.B. / Sweden), Roche (Switzerland), Bristol-Myers Squibb (USA), Wyeth (USA), Abbott (USA), Lilly (USA). Some of them merged later, like Pfizer, which bought Wyeth in 2009.
} 
and also to access foreign markets, they have also started to internationalise (to a lesser extent), mainly in the US and then Europe, in order to compensate for their lack of knowledge in life sciences (Mahlich, 2010). The first foreign R\&D centre was opened by Esai in 1987 in Massachusetts. It was followed by other research facility openings, acquisitions in the US and the UK (Fugisawa, Takeda, Kyowe Hotto, ...). In the mid-2000s, biotech firms were acquired by leading Japanese firms (Takeda bought Syrrx in 2005 and Paradigm Therapeutics in 2007).

IP rights are of particular importance in the pharmaceutical industry, as new drugs or improvements to existing drugs are costly to develop and easily imitated at relatively low cost. However, many countries with strong patent protection for other industrial products and processes have not always provided strong protection for pharmaceutical inventions. In 1970, only the US, the UK, France and Germany allowed new pharmaceutical products to be patented in other countries, only pharmaceutical related processes were eligible for patent applications.

Pharmaceutical product patents started to be patentable in Japan in 1976, in South Korea in 1987, and in China in 1993. The 1995 Trade-Related Aspects of Intellectual Property Rights (TRIPS) Agreement required all member countries to provide pharmaceutical product and process patents. In 2010, more than 90 per cent of all countries offered pharmaceutical product patents. From the Pharmaceutical Intellectual Property Protection (PIPP) Index, defined by M Liu and S La Croix to evaluate the overall level of Pharma IP protection in countries, the level of protection in the countries included in this study is rather high (US: 4.51 (the highest value), Germany, Japan and the UK: 3.18, France: 2.92 and Korea: 2.02) (Liu and La Croix, 2015).

Patent rights differ among pharmaceutical patents: process patents are considered as weaker than product patents. The former do not prevent cost-based competitive entry by entrants with superior manufacturing processes while the latter block entry by competitive (or generic) products. In order to extend the exclusivity periods and delay the entry of generic products, firms follow an evergreening stratetgy that consists in filing at different period of time separate patents on the same product's active ingredient but introducing changes in methods of use, formulations, ...

Following TRIPS Agreement, the effect of patent policy on the welfare loss associated with higher prices in emerging markets was largely evaluated (Chaudhuri et al., 2006). More broadly, the patent rights impact on the rate of creation of new innovations and on their further diffusion. National patent and governmental price regulation policies impact on the speed at which new drugs become available in countries. With a set of more than 600 new drugs $^{5}$, Cockburn et al. (Cockburn et al., 2016) show how factors (health policy institutions, economic and demographic factors) that make markets more profitable speed up drug diffusion. Moreover, more extensive patent protection accelerates diffusion of new drugs while price regulation delays it.

\footnotetext{
${ }^{5}$ The overall diffusion was quite limited : the mean number of countries in which a drug was launched was 22.4 (out of a possible 76 ). Only $39 \%$ of the drugs were launched in ten or fewer countries, and only $41 \%$ were launched in more than 25 countries.
} 
Governments have interest in allowing competition to decrease prices when patents expire. This competition takes the form of "generic" firms who enter drug markets with a copy of the branded drug at a lower price. Larger markets and large margins attract larger generic entry. In western developed countries, the diffusion of generic products after patent expiry varies significantly across countries (Magazzini et al, 2004). Regulatory environments play a role and policies supporting price competition through the diffusion of generics after patent expiration seems to be effective. The presence of licensed products on the market slows down the generic entry. In BRIC and low income countries unable to afford patented drugs, nor relatively expensive generics from western multinational firms, inexpensive generic drugs coming first from India and, to a lesser extent from China widely diffuse. The powerful Indian generic drug manufacturing sector is globally competitive and has, thus far, adapted to over 200 different national markets across the globe, including the highly regulated drug markets of Japan and the major Western economies (Jakovljevic, 2014).

\subsection{The dataset}

This research uses the worldwide patent indicator (de Rassenfosse et al., 2013) based on the compilation of priority patent applications from more than 170 patent offices offered in the Patstat database (version of October 2011). This overcomes the strong national bias which hampers indicators based on data from a single patent office, covers all patented inventions and clearly reveals the local nature of inventive activity (Rassenfosse et al. (2013). In this respect, the worldwide indicator based on all priority patents provides a global view of MNC internationalisation as it also integrates patents outside mainstream countries. Nevertheless, this worldwide indicator has one drawback and treats equally patents applied for at offices whose rules for patenting are more or less demanding, thus introducing an institutional bias. It thus includes a high share of singleton patents, i.e. patents that have only been applied for in the applicant home country without any geographical extension. This research avoids the bulk impact of this bias by considering only priority patents that have been applied for in at least in two different patent offices, in order to eliminate the lowest value patents. This research exploits a database that identifies the priority patents applied for by the largest industrial firms in the world. It has been built in three stages. First, a set of 2,800 large industrial R\&D performers has been established by complementing the list of 2,000 firms identified in the 2009 edition of the IPTS "Industrial R\&D Investment Scoreboard", and with top patent applicants from the WIPO, EPO and USPTO rankings. Second, relying on the Orbis database edited by Bureau van Dijk Electronic Publishing, we have identified the subsidiaries included in the consolidated perimeter of these industrial groups (considering only subsidiaries in which one of the Global Ultimate Owners had more than $50.01 \%$ of shares). Corporations' boundaries are based on a single outlining of subsidiaries established in 2008 .

Third, the names of the firms and their subsidiaries have been looked for as potential applicant names in the Patstat database after several stages of name cleaning, name harmonising and filling of missing information. A detailed presentation of the building and characterisation of this large firms' database is provided in Laurens et al. (2015a). For this research we also include a step to fill missing information in artificial patents, in particular 
those due to claimed priorities, i.e. resulting from applications claiming a priority that cannot be found in Docdb families ${ }^{6}$.

\subsection{Sample analysis}

For this research, we have restricted the set of firms to those that have applied for at least five priority patents in both the three-year periods 1994-1996 and 2003-2005, and which retained the European, US and Japanese firms in the pharmaceutical sector (sector 4570 of the Industry Classification Benchmark (ICB): "Pharmaceuticals \& Biotechnology"). Geographical information concerns the national origin of corporations and the places where the inventions occurred. This has been identified according to, respectively, the location of the corporations' headquarters and the personal addresses of inventors. When more than one country appears in inventors' addresses in a given patent, a fraction is attributed to each country (fractional counting).

We obtained a corpus including 76 pharma firms: 30 of them are located in the US, 15 in Japan and 31 in Europe. Counting patents is realised by counting the number of simple patent families $^{7}$ (docdb families in the Patstat database). Detecting patent coverage is done by retrieving the name of the different patent offices in each docbd patent family. We consider only type A priority patents (we did not select type W, which corresponds to PCT patent applications). This avoids double counting PCT applications: we only consider these when they enter their regional or national phase). Our set of pharma firms has applied for 17,633 priority patents between 2003 and 2005 (Table 1). One third of them (5,776 patents) are transnational priority patents, i.e. patents applied for in at least two different patent offices worldwide. US firms, Japanese firms, German firms and firms from small European countries each account for approximately $20 \%$ of these.

Table 1: Number of firms and patent families for priority patents and transnational priority patents

The share of transnational priority patents over the total number of priority patents differs according to the location of the firm's headquarters. It ranges between $40 \%$ and $50 \%$ in most European countries and is equal to $25 \%$ in the US and $20 \%$ in Japan. Taking into account that priority patents most often protect domestic markets, it is not surprising that American and Japanese firms focused first on the domestic market, as these countries are the two largest markets for pharmaceuticals. In order to characterise the geographical extension of IP in MNEs, we rely on information given in patent docbd families. For each transnational priority patent, we compute from the list of the geographical applications of its docbd family if it is a triadic patent (applications at EPO, USPTO and JPO), a new triadic patent (triadic patent plus

\footnotetext{
${ }^{6}$ Completion of information on artificial patents relies on the retrieval of information from the nearest completed patent in the Inpadoc patent family, which includes the artificial patent to be completed. The retrieved information includes the names and addresses of inventors and applicants, ICP classes and docdb family id (Laurens et al., 2017).

${ }^{7}$ A simple patent family includes all patent applications that share the same active priorities.
} 
application at SINO (China) and KIPO (Korea)), or not. We also compute transnational priority patent applications at each of the five patent offices (Table 2). In our empirical study we compute data related to triadic and new triadic patenting. Our study aims to account for why a firm patents these.

Table 2: Share of patents with IP protection in the different countries or zones.

Table 2 shows that the US and Europe are the two regions where most transnational pharmaceutical patents are applied for, either as priority patents or as a further geographical extension (76\% of transnational patents are applied for both at the USPTO and the EPO, more than $80 \%$ in one of these two offices). This holds true for firms from western countries, but also for Japanese ones. This indicates that, on the one hand, western countries are considered to be large markets for pharmaceutical products wherever the firms are located, and, on the other hand, that Japanese pharma firms have reached an invention level in pharmaceuticals that permits them to apply for IP protection in western countries. This is also in line with the fact that the value of the PIPP index for pharma IP protection in Japan is similar to those of European countries. In the mid-2000s, it is thus no longer a huge step for the largest Japanese pharma firms to extend their pharma patents worldwide. They have already opened and started to compete on international markets by "creating a triad network between Japan, the US and Europe" (Odagiri and Yasuda, 1996). The attractiveness of the Asian pharmaceutical markets is much lower (with the exception of the high level of patents that Japanese firms apply for in their domestic market). China is the first Asian country where western firms apply for pharma patents (47\% of transnational patents originating from western firms designate China as a country for IP protection), before Korea (32\%) and Japan $(17 \%)$. Such evidence may appear to be paradoxical since the Chinese system of patents is still acknowledged to be weak. In fact, we now know much more about the motives of patenting in China. Among the key factors, we note firms' expectations on the future development of China's appropriability system and the use of patents as a signalling mechanism (Keupp et al., 2012). Moreover, competition between foreign firms in China is becoming fierce and accounts for the growth of foreign patenting in China ( $\mathrm{Hu}, 2010)$. China is also a country where firms locate clinical trials for limited costs.

The leading position of China as a country in which to search for IP can be compared with the increasing trend for western firms to establish pharmaceutical facilities in China (after China's WTO entry in 2001, most of the big pharma companies entered the Chinese market, manufactured drugs and carried out less expensive medical and clinical trials and R\&D), despite a rather fragmented but promising market for drugs (Grimes, and Miozzo, 2015). As a smaller but also promising and growing market Korea receives approximately one third of the applications of transnational drug patents, while Japan lagged behind, receiving only $17 \%$ of transnational pharmaceutical patent applications. This low level of applications from western drug pharma in the early $20^{\text {th }}$ century shows that Japan, the second largest drug market, with reinforced IP protection, was still considered to be a difficult market to penetrate by foreign 
firms, perhaps due to the loyalty of customers to domestic drugs and strong price regulation ${ }^{8}$. This acts as a barrier to the entry of foreign firms in the Japanese market. As a consequence we have to consider, as an asymmetric position, a low share of transnational patent applications in Japan by western pharma firms and the conversely high level of applications in western countries by the Japanese. It explains why the share of triadic and new triadic patents in transnational patents differs across western and Japanese pharma firms. For the latter, almost $75 \%$ of their transnational patents are triadic, and almost one quarter of them are new triadic patents. These shares are respectively only $15 \%$ and $4 \%$ for western firms. The high level of triadic and new triadic patents in the transnational patent portfolios of Japanese firms is specific to the pharmaceutical industry (we did not observe such a trend in the ICT sector).

\section{Modelling, Econometric Strategy and Variables}

\section{1. Modelling and econometric strategy}

We model the decision to extend patent protection internationally as follows. We assume the decision to be governed by a cost/benefit process. In other words, the decision will depend on the net profitability of the international coverage of a firm having already applied for one priority patent. A firm extends its IP assets abroad according to the scale of the economic benefits it can receive. Numerous empirical studies tend to show that a firm patents in foreign countries when the market is considered to be important (Grupp and Smoch, 1999). Recently, this finding has also been confirmed for firms in emerging economies (Chang, 2010; Hu, 2010). As a consequence, one of the main drivers of IPI is the economic size of the market in which the firm searches to exploit its new knowledge (Chang, 2010). The need for effective protection abroad becomes more crucial when domestic firms clearly have strategies of imitation (Hu, 2010; Huang and Jacob, 2014). In other words, the type of technological competition matters here. Then we suppose that a firm that has invented in any foreign country is interested in patenting, on the one hand, in order to protect its inventions worldwide, but also in order to make profits mainly through licensing, on the other. For these reasons we assume there are two determinants of international patent coverage: the level of firm technology (or R\&D) internationalisation and the firm's presence in a country or continent. Of course, cost matters as well. Unfortunately, we have not gathered information about the cost of triadic or new triadic patenting. Due to the fact that firms must pay more for a new triadic extension we can infer that a firm has fewer incentives to use a new triadic unless the economic advantages significantly offset the additional cost. This argument explains why firms patent less, as far as new triadic patent is concerned ${ }^{9}$.

We start with the net profit (profits - costs) as a crucial variable triggering the process of international extension ${ }^{10}$. In our framework two important variables affect the net profit

\footnotetext{
${ }^{8}$ The reasons that have initiated the opening of Japanese drug firms to foreign markets could be the same as those that prevent the interest of foreign firms in the Japanese market.

${ }^{9}$ Chan (2010) considers many countries. Our framework, based on triadic patenting, is a little different.

${ }^{10}$ The value of the invention( or the invention quality) (Chan, 2010) plays an important role in firms' decisions to patent abroad. Unfortunately, a measure of patent value is missing in our paper. The problem, in fact, is the
} 
variable: the level of firm's R\&D internationalisation and the firm's presence in large countries or continents. In our modelling the timing of this process is not taken into account. This means it is identical to extend internationally in the wake of the priority application, or a few years later..

We consider the patent as the unit of analysis. We are basically in a situation where two alternatives occur: once priority patents have been applied for in two countries (transnational patents), triadic (or new triadic) extensions may be applied for or not. In the frame of our analysis the dependent variable is binary: it is equal to 1 when the firm extends a transnational priority patent as a triadic patent (or new triadic), and zero if it does not. In a binary response the framework interest lies in the response probability:

$\operatorname{Prob}\left(y_{i}=1\right)=F\left(\beta^{\prime} x_{i}\right)$

where $F($.) indicates a cumulative distribution function, $x i$ the explanatory variables and $\beta$ the vector of the parameters to be estimated. As we here assume $\mathrm{F}($.$) is the standard normal$ cumulative distribution function, we are explicitly in the well-known frame of the probit model. In order to check our hypotheses, we test several probit models. Each of them gives the probability of a single patent becoming triadic or new triadic as a function of specific regressors. Each independent variable is related to a firm's characteristic.

\subsection{Variables}

Dependent variables:

We chose triadic patenting as an indicator of IPI. Due to the fact that patenting in Korea (a large country patentor) and China (a very large market with consistent technological activity) is now crucial but not taken into account in triadic patenting, we also use new triadic patenting as another variable (see previous section for definition).

Regressors: Our research aims to identify the factors explaining why firms apply for a triadic (or new triadic) patent once they have already obtained a single patent through a national office. The main independent variables are: firm_intercontinental patent_pct, defined as the share of transnational priority patents invented overseas in the patent portfolio of the firm when the foreign inventor is located in a continent that differs from the firm's HQ. This variable gives a measure of IT. As we are dealing with triadic patents, internationalisation across continents was considered as (and indeed was) more relevant than the total

\footnotetext{
following. With respect to patent value we are not interested in the ex-post value but in the ex-ante one. The ex-post value is the value evidenced at the end of the patent life cycle which is strongly impacted by firm strategy in terms of firm presence in foreign markets and the localization of R \& D activity. Therefore, it is impacted by the fact that the patent is becoming triadic or new triadic. It cannot be used as an independent variable that would explain the patent extension. A good measure of patent value should be calculated just after the application of the priority patent as an expected potential economic value of the patent. We do not have the means to calculate this. The patent citations scheme does not work here. We tried to put in the regressions the number of inventors related to each single invention (given in the patent document) as a proxy for the patent value. But we have never found any significant effect of this variable (the estimation results are not reported here)..
} 
internationalisation percentage that also includes regional $R \& D$ internationalisation in surrounding countries ${ }^{11}$.

The three following variables indicate if any firm has or has had a presence or a commercial activity in large markets. They aim to signal that in these countries a firm has profitable activities. They play the role of potential determinants for IPI: firm_presence_JP\&US\&EU, which signals the presence of the firm's entities both in Japan, the US, and in a European country. The indicator is built from the perimeter of the firm given by Orbis (data 2008). For a given firm if, in the firm's consolidated perimeter, Orbis reports at least three subsidiaries, one in the United States, one in Europe and one in Japan, the value of the "firm_presence_JP\&US\&EU" is set to one; otherwise it is zero. Similarly, when the variable "firm_presence_JP\&US\&EU\&KR\&CN" is set to one for a firm, it means that in the Orbis database, the firm's perimeter includes subsidiaries in the United States, Europe, Japan, Korea and China. It has also been built up thanks to Orbis (data 2008). As an independent variable, it is more relevant for accounting for the new triadic patent. At last, we have built a binary indicator "firm_drug_triadic_market" to signal whether the firm has already developed commercial activities in both the Triadic zone prior or during the period of time the patents were applied ${ }^{12}$. It relies on information given in drug approval databases and firm's websites. The "firm_presence_JP\&US\&EU" indicator determines the presence of a firm's entities in each zone of the Triadic but does not allow to determine the type of the activity the firm's entity and it relies on information of the firm's perimeter in 2008, i.e. after the period of time of the patent application; conversely, the indicator on "firm_drug_triadic_market" aims at capturing information on commercial activities of the firm in the Triadic market before the patent application. However one of its drawbacks is linked to the fact that it focuses only information related to the drugs' market and does not encompass all the firm's products ${ }^{13}$.

We have included variables showing that the firm has R\&D activities in Japan or in relation to Japan (patent_JP_invt_pct), or in other Asian countries (patent_Asian_inventors_pct). We add the following control variables: firm_ log_nber_priority patent, the logarithm of the total number of priority patents applied for between 2003 and 2005 by the firm, controls for the firm size and technological activity.

A firm that is large in terms of its technological activity has better skills in IP management. firm_R\&D intensity. This variable measures firm $R \& D$ or technological intensity. It is defined as the share of firm $R \& D$ investments over sales. We know there is a positive relationship between $R \& D$ or technological intensity and the propensity of the firm to patent inventions (Cohen et al., 2000). Firm_pharmaceutical_field_patent_pct is the variable for controlling the likely effect of the sub-technological field in which the firm applies for patents. For each firm, it is defined as its share of transnational priority patents related to the technological field "pharmaceuticals". Our corporate patents are related first to the field of

\footnotetext{
${ }^{11}$ See Laurens et al. (2015a) for more details of the percentage of the regional and intercontinental internationalisation of patents.

12 Information related to drug approvals is not easily available for China and Korea in the period of time of interest.

13 When we use this variable in the models we discard from the model the patents applied by firms with no commercial activity at all in any country of the Triad. For these firms we consider that our indicator only centered on drugs to track their commercial activity is not appropriate.
} 
"Pharmaceutical" and then to "Organic fine chemistry" and "Medical technology" (see Annex 1 for further details).

We expect that the motives of firm R\&D internationalisation should matter. In order to assess these effects, we compute the different firm strategies by using a typology built up with the index of revealed technological advantages (for a more detailed analysis see Le Bas and Sierra, 2002; Narula and Zanfei, 2005): Strategy 1: Technology-seeking foreign direct investment (FDI) in R\&D. This type of strategy is directed towards offsetting home country weaknesses in a given technological field by selecting a host country with proven strength in the desired technology. Strategy 2: Home Base Exploiting FDI in R\&D (Kuemmerle, 1999). This is the exact opposite of the first strategy. The rationale for the investment here is to exploit existing firm-specific capabilities in foreign environments. Strategy 3: Home Base Augmenting FDI in R\&D. The third type of strategy consists in targeting technologies in which the investing firm has a relative advantage at home and the host country is also relatively strong. This kind of investment has accordingly been labelled as "Home BaseAugmenting” FDI in R\&D. Strategy 4: Market-seeking FDI in R\&D. The fourth type of strategy corresponds to situations where a firm invests abroad in technological activities in which it is relatively weak in its home country and the host country is also relatively weak. The motivation for this fourth type of strategy is thus apparently not technology-oriented.

The literature shows that Strategy 2 and Strategy 3 are the dominant ones (Le Bas and Sierra, (2002), Laurens et al., 2015a; Laurens et al., 2015b). For each firm in the sample we calculate the amount (and the percentage) of patents matching each strategy. We hypothesise that the variables related to strategy 1 (firm_TS_patent_pct ) and strategy 4 (firm_MS_patent_pct) have a positive impact on the probability to apply a triadic patent. The more a firm searches for new technological knowledge abroad (Strategy 1), the more it will be prone to protect it through patenting. In the framework of Strategy 4 the firm will patent abroad in order to protect its market share. We also define variables for strategy 2 (firm_HBE_patent_pct) and strategy 3 (firm_HBA_patent_pct).

Table 3: Overview of the explanatory variables: definition, type and statistics

\section{3. Descriptive statistics and Empirical Models for estimation}

Table 3 provides evidence regarding a firm's R\&D internationalisation, on the one hand for western (US and EU) firms and, on the other hand, Japanese firms. Not surprisingly, the level of $\mathrm{R} \& \mathrm{D}$ in the overseas internationalisation of patents in the western firms (16\%) largely exceeds the internationalisation of patents in the Japanese firms (3\%). This large difference in internationalisation is in accordance with data from the literature which claims that the opening of R\&D in Japan was much slower and more limited than in western countries. There is also some difference in the internationalisation of patents originating from US firms and European firms (not shown here): European firms have a higher level of internationalisation that results from a high level of R\&D internationalisation within Europe 
(34\%); overseas internationalisation remains higher for US firms (30\%) than European ones $(10 \%)$. Overseas internationalisation takes place mainly between Europe and the US, whereas overseas internationalisation involving Asian inventors remains rare in western regions (around $4 \%$ of all inventors). Furthermore, the pharmaceutical sector is among the most internationalised sectors in both zones (as already observed in many papers). In our data set, overall R\&D internationalisation, including both regional and intercontinental internationalisation in the pharmaceutical sector, is $43 \%$ for US and European firms and $13 \%$ for Japanese firms. It is $25 \%$ for western firms and $5 \%$ for Japanese ones, when considering all industrial sectors. Considering now the share of firms that have established facilities either in each country of the Triad or in the Triad, but also in Korea and Japan, the difference between Japanese firms and US \& European firms is less pronounced: in both zones, the share of firms present in the Triadic countries is approximately 40\%; however, firms from western countries are more often also present in China and Korea (23\% of them) than Japanese ones (13\%). The share of firms that already have (or plan to have) a market activity related to drugs in the three zones of the Triad before the patent applications is quite similar for Japanese firms (36\%) and for US and European firms (41\%). The statistics shown here indicate that in the mid-2000s, pharma firms in eastern and western countries have developed both international networks of internal facilities and commercial activities in the main global markets to the same extent, but as far as their levels of $R \& D$ internationalisation are concerned, there is a significant contrast between Japanese firms and western ones.

As far as the strategy of internationalisation is concerned, the Home Base Augmenting strategy dominates in the two regions above the Home Base Exploiting ones. The distribution across technological fields of pharmaceutical patents in Japanese and US \& European firms shows differences: Japanese transnational priority patents are focused on "Pharmaceutical" (69\%) and "Organic fine chemistry" (9\%); the US \& European firms show a different technological profile where, besides "Pharmaceutical" (42\%) and "Organic fine chemistry"» (11\%), "Medical technology" (17\%) is the second largest field (see Annex 1).

We have previously noted the large share of triadic and new triadic patents in the transnational patent portfolios of Japanese firms, which contrasts with the share in the portfolio of US and EU firms. This has an important consequence for our econometric exercise. The firm's behaviour related to IP coverage is not the same across continents. In addition, the position of Japanese firms related to $R \& D$ internationalisation also differs from those of US and EU firms. As a consequence, we assume that the relationship governing the probability for a patent to be extended internationally differs across continents, between US and EU firms on the one hand, and Japanese firms on the other. Preliminary econometric works not reported here confirm that we cannot deal with these important differences through fixed effects models. As a consequence, we run separate estimations after splitting the firms' sample in two parts: one related to US and EU firms, the other one to Japanese firms only. For the US and EU firms set, we build up three models because we are hindered by the collinearity between variables (see Annex 2). For each of them, we put the main explanatory variable firm_international patent_pct, measuring the level of firm R\&D overseas internationalisation, as our main variable of interest. The distribution of the share of triadic patents according to the firm internationalisation is shown in Annex 3 for western and Japanese firms. Model 1 is in some sense our basic model. Besides the main explanatory variables, we find control variables. We control for the firm's size of technological activity 
with the firm_ log_nber_priority patent. Pharmaceutical firms can roughly innovate in two different large classes: new drugs ("pharmaceuticals" or "fine organic chemistry" technology fields), and new technological processes related to pharmaceuticals ("measurements", "medical equipment", "analyses of biological material" technology fields). We hypothesise that the process of internationalisation might differ for the two types. As a consequence, we control for that with firm_pharmaceutical_field_patent_pct. Finally, we control for firm R\&D intensity. The basic underlying idea is, the more a firm is R\&D-intensive, the more it manages intangible resources and the more it should protect its IP assets worldwide. Model 2 crucially incorporates the variables related to the second variable, securing rents from foreign markets through the sale of new products or licensing. We also use another variable that measures the extent to which a firm has a presence in Asian countries. The quantitative variable patent_Asian_inventors_pct gives a precise measure of a firm's presence in Asia. In Model 3, besides our main variables of interest, we use the following three variables: firm_R\&D intensity, firm_local_presence JP\&US\&EU (or firm_local_presence JP\&US\&EU\&KR\&CN) as an indicator of the presence of entities of the firm, located in the countries where the firm applies for IP protection. The larger this variable, the larger is the probability to apply the triadic (new triadic). Because of the collinearity between the main explanatory variable, "firm_international patent_pct", and the "firm_drug_triadic_market" (see Annex 2), "firm_drug_triadic_market" could not be used as an alternative variable to test hypothesis 2 in Model 3.

Patent_JP_invt_pct, as a variable to measure the presence of an inventor located in Japan among patent inventors. This variable seems to be important for triggering an application in the JPO. With this model we intend to test the robustness of the variables set out in Model 2. These three models have been built up for European and US firms. As noted previously, the specific patenting strategy developed by Japanese firms forces us to slightly modify the specification of these models. We estimate a Model 1a, a close model of Model 1. The number of independent variables differs due to collinearity concerns. We retain a second Model 2a, in which we put the variable firm_presence_JP\&US\&EU, indicating if there is a presence of Japanese firms abroad.

As "firm_drug_triadic_market"could not be used in any of the models described above to test the effect of the firm's R\&D internationalisation, we separately run other regressions to check if a firm market activity in the Triad prior to the patent applications may explain the propensity to further apply triadic patents. This last aspect is not central to our analysis and this indicator may not be very robust for firms where drugs are not the only products. The models were run for the propensity to apply triadic patents in US and European firms where at least $10 \%$ of the patents dealt with drug related technologies. Results are shown in Annex 4.

\section{Estimation and results.}

For each model we run a probit regression for each of the two dependent variables: triadic and new triadic patents. In order to test our central hypothesis related to the impact of R\&D internationalisation we present two different specifications: linear and quadratic. At this stage one point deserves crucial attention. We observe in 2010 if the priority patents applied for between 2003 and 2005 have been spread out at the global level through triadic or new triadic 
patents. We certainly do not have all the triadic and new triadic patents coming from the priority application carried out in 2003-2005. But the review of triadic patenting between 2003 and 2010 shows that in 2010 an asymptote was reached ${ }^{14}$. In general, the patents are extended quickly after the priority application.

We first comment on the results for the US and European firms (table 4) and then for the Japanese firms (table 5). We will end the section by comparing the trends in the two sets.

Table 4: Determinants of triadic and new triadic IP protection in patent portfolios for US \& Europe pharmaceutical firms.

Table 5: Determinants of triadic and new triadic IP protection in patent portfolios of Japanese pharmaceutical firms.

Regressing the presence of triadic or new triadic patents in US or European firms in the different models always shows that the variable related to the level of R\&D overseas internationalisation is very significant, as well as the variable reflecting the firm's presence in the triadic countries. Our basic assumptions that the firm's R\&D internationalisation, but also commercial or economic activities, matters in the firm's international IP management are verified. One important result is that the different estimated coefficients related to $R \& D$ internationalisation show a real stability through the different Models and dependent variable specifications. Moreover, some interesting trends emerge ${ }^{15}$ :

1. The quality of fit (here the pseudo $\mathrm{R}^{2}$ ) is always larger for the quadratic form than for the linear form of $\mathrm{R} \& \mathrm{D}$ internationalisation. We also note that the coefficients related to the linear relation is not always significant. This indicates that, contrary to our expectations, the relation between $R \& D$ internationalisation and the probability to apply for triadic (or new triadic) patents is not growing monotonously. We will discuss this important finding later. As a consequence, our hypothesis 1 as we saw as the more relevant cannot be accepted as a general trend. By contrast the quadratic relation (expected as a rather secondary picture) appears as a more likely general trend.

2. Generally speaking, the quality of fit is better when we consider triadic patenting behaviour (compared to new triadic patenting). To put it simply, our models better explain the propensity to apply for triadic patents than for new triadic ones. This is partly due to the weaker explanatory power of the central variable, R\&D internationalisation.

\footnotetext{
${ }^{14}$ It is possible that we have missed a late extension of priority patents applied for between 2003 and 2005 that was not included in the database version (Patstat 2011). However, our tests have shown that the shares of triadic or IP5 patents reach an asymptote three years after the year of priority patent filing. As an example, for a population of priority patents applied for in 2003, the share of patents that are extended as triadic or IP5 patents is 13\% in 2004, 17\% in 2005 and 19\% in 2006, 2007, 2008 and 2009.

${ }^{15}$ Year dummies related to application patent filing year do not change any estimated coefficient.
} 
3. These results hold true after controlling for firm technological activity size, $R \& D$ intensity ${ }^{16}$, drugs or pharmaceutical materials (see Model 1).

4. When we put in the regression beside the central variable $R \& D$ internationalisation factors indicating firm presence (for example presence of Asian inventors in an R\&D team), or a proxy for technology-seeking foreign direct investment (FDI) in $R \& D$, these variables have a significant explanatory power. Let us point out that market strategy plays a role in triadic patenting, not in the new triadic one. Our hypothesis 2 is confirmed.

5. Models 3 and 4 confirm the later findings: a local presence (whatever its form) or a prior market activity is a positive phenomenon playing a role in favour of a triadic (and new triadic but with a weaker effect) patenting.

6. The presence of Japanese inventors in an invention team, is a positive factor playing in favour of triadic (and new triadic but with a weaker effect) patenting

6. The results of the regression for Japanese firms (Table 5) are opposite to those obtained for western pharma firms. For Japanese firms, the estimations tell us that the quadratic form does not provide significant results. More surprisingly, the linear relation shows a significantly negative slope with regard to the $R \& D$ internationalisation proxy variable. It means that the less Japanese firms internationalise their R\&D, the more they apply for triadic patents. This singular result is totally opposed to our hypothesis 1 . Such a result contradicts what we have previously found for European and US firms ${ }^{17}$.

7. Another difference between Japanese and western firms is that the type of inventions also differs: Japanese firms preferred to apply for triadic patents for drugs, compared to processes. Model 2a suggests the variable presence of Japanese inventors (measured by their share) explains the new triadic patenting, but not the triad one. We would suggest that for Japanese firms, our results have described a situation where firms are able to compete on western markets because they have to catch up with western firms and follow a national plan to compete in the pharma sector worldwide. The behaviour of Japanese firms in patenting trends is more related to Japan's national policy.

\section{Conclusion}

To return to our initial issue concerning the role of $R \& D$ internationalisation in IP internationalisation, we have found that, as a first approximation, IP internationalisation in western (US and EU) firms is significantly correlated to R\&D intercontinental internationalisation. Our linear models do not give the more significant pictures. By contrast the quadratic models have better goodnesses of fit. These models would suggest that there is as an "optimum" level of R\&D internationalisation related to the share of triadic and new triadic shares peaks (inverted U-shaped relationship). Above a certain threshold, the propensity to apply for triadic and new triadic patents would decrease. To explain this tentative trend, we put forward the following assumption that could be tested by further

\footnotetext{
${ }^{16}$ In general, R\&D intensity does not have any explanatory power in our regression, with the exception of Model 3 , in which this variable has a negative, weakly statistically significant impact for triadic patenting only. ${ }^{17}$ At this stage it is important to recall that very few Japanese firms are internationalised in terms of R\&D (see among others Le Bas and Sierra, 2002).
} 
research. It might be that a life cycle of IP internationalisation plays a role here. When a firm begins to internationalise, it patents its own $R \& D$ internationally a lot. In this context, the two processes of IT and IPI are growing together. Because triadic and new triadic patenting is costly, the firm learns step by step in order to manage its patent behaviour more effectively. As a consequence, when a firm continues to internationalise its $R \& D$ it patents less because it patents more efficiently. In this new context, the relation between IT and IPI can be the reverse. Besides, it seems that the presence of Japanese inventors, or to a lesser extent Asian inventors, also has an important effect on the applications of triadic and new triadic patents. This could indicate that what matters for triadic or new triadic patent applications in western pharma firms is not the overall $R \& D$ level of internationalisation but the location of $R \& D$ activity. Locating $\mathrm{R} \& \mathrm{D}$ in the triadic and new triadic countries is correlated to an entry in these markets, thus a firm must protect these inventions.

The fact that we better explain triadic patents than new triadic patents may result from the idea that firms do not have the same motivations when protecting their inventions in Japan, the second largest global market, with a high level of health demand, as in China (or Korea), smaller but promising markets where it might be important to be located because of growing competition. On the one hand, China offers many interesting opportunities for the pharmaceutical industry since it is much easier and cheaper to conduct clinical tests. It might be a strategy for pharmaceutical firms to start marketing and commercial activities in China with products that are not the very best new developments, but rather 'me too' products. In this scenario, indicators linked to $R \& D$ activities might not be as relevant as when dealing with more advanced countries with a high level of health consumption.

Another factor playing a role is the nationality of the firms. US firms and European firms do not manage IP internationalisation in the same way in Asia. When they protect their inventions in Asia, US firms prioritise applications in Japan, while European ones prioritise applications in China. Several reasons may explain this behaviour. When Japanese firms internationalised in the 1990s, they first started to enter the US market (before European firms). In response, the US firms leading the sector with their mostly unchallenged skills in molecular biology and biotechnologies might have reacted quickly to the threat and decided to break into the difficult Japanese market first. Coming to Asia later, European firms could have decided not to compete with US firms in Japan, but rather to try to enter other promising and less competitive markets, such as the Chinese market.

Finally, we wish to state that there is a rather strong and persistent effect of the type of inventions in the propensity to apply for triadic or new triadic protection. Drug-related inventions will not be protected to the same extent as other types of inventions, which are more related to processes. We do not have a clear understanding of this aspect. If the protection of drug products was not allowed in most countries in the 1980s, this was not true after the TRIPS agreements. However, it could be linked to the fact that countries like Japan have maintained barriers to protect their market, for example by requiring additional clinical tests on the Japanese population for drugs that had been approved in western countries. These practices, which created additional costs and risks for foreign pharma firms in Japan, ended at the beginning of the 20th century, but may still explain our observations a few years' after. 


\section{References}

Abramovsky, L., Griffith, R., Mcartney, G., and Miller, H., (2008), "The location of innovative activity in Europe", IFS Working Papers W08/10. Institute for Fiscal Studies, UK, Downloaded from_http://www.ifs.org.uk/wps/wp0810.pdf_.

Allred, B. B., and Park, W. G., (2007), "Patent rights and innovative activity: evidence from national and firm-level data", Journal of International Business Studies, vol. 38, n 6, pp. 878-900.

Almeida, P., (1996), "Knowledge sourcing by foreign multinationals: patent citation analysis in the U.S. semiconductor industry", Strategic Management Journal, vol. 17, Winter special issue, pp. 155-165.

Ambos, B., (2005), "Foreign direct investment in industrial research and development: A study of German MNCs", Research Policy, vol. 34, n 4, pp. 395-410.

Archibugi, D., and Michie, J., (1997), Technology, Globalisation and Economic Performance, Cambridge: Cambridge University Press.

Bartlett, C. A. and Ghoshal S., (1989), Managing Across Borders: The Transnational Solution, Brighton: Harvard Business School Press.

Baudry, M., Dumont B. and Dierx A., (2006), "Measuring Inventive Performance of the OECD Countries Using Triadic Patent Families: Reinventing the Lisbon Challenge", in: S. Mundschenk, M. H. Stierle, U. Stierle-von Schütz, and I. Traistaru, (eds.), Competitiveness and Growth in Europe, chapter 9, Cheltenham: Edward Elgar Publishing.

Bjorvatn, K. and Eckel, C. (2006), "Technology Sourcing and Strategic Foreign Direct Investment", Review of International Economics, vol. 14, $\mathrm{n}^{\circ}$ 4, pp. 600-614.

Blind, K., and Frietsch, R., (2003), Sector-based multidimensional forecasting model (seform), report to the European patent office within the research programme: improvement of methods for forecasting patentfilings, Karlsruhe: Fraunhofer ISI.

Bosworth, D., (2006), "The Management of Intellectual Property: introduction", in : L. Derek Bosworth and E. Webster, (eds.), The Management of Intellectual, Cheltham: Edward Elgar.

Bottazzi, G., Dosi, G., Lippi, M., Pammolli, F., Riccaboni, M. (2001), "Innovation and corporate growth in the evolution of the drug industry", International Journal of Industrial Organization, vol. $19, \mathrm{n}^{\circ}$ 7, pp. 1161-1187.

Branstetter, L., (2006), "Is Foreign Direct Investment a Channel of Knowledge Spillovers: Evidence from Japan's FDI in the United States", Journal of International Economics, vol. 68, February, pp. 325-344.

Cantwell, J., (1995), "The globalisation of technology: what remains of the product cycle model?", Cambridge Journal of Economics, vol. 19, ${ }^{\circ}$ 1, pp. 155-174.

Cantwell, J., and Iammarino, S., (2000), "Multinational corporations and the location of technological innovation in the UK regions", Regional Studies, vol. 34, n 4, pp. 317-332.

Chan, H.P., (2010), "The Determinants of International Patenting for Nine Agricultural Biotechnology Firms", The Journal of Industrial Economics, vol. 58, n 2, pp. 247-278.

Chaudhuri, S., Goldberg, P., and Gia, P., (2006), "Estimating the E§ects of Global Patent Protection in Pharmaceuticals: A Case Study of Quinolones in India", American Economic Review, vol. 96, $\mathrm{n}^{\circ}$ 5, pp. 1477-1514. 
Chen, Y. C., (2008), "Why do multinational corporations locate their advanced R\&D centres in Beijing?", The Journal of Development Studies, vol. 44, n 5, pp. 622-644.

Cockburn, I. M., Lanjouw, J.O., and Schankerman, M., (2016) "Patents and the Global Diffusion of New Drugs", American Economic Review, vol.106, n 1, pp. 136-64.

Cohen, W. M, Nelson, R. R., and Walsh, J. P., (2000), "Protecting Their Intellectual Assets: Appropriability Conditions and Why U.S. Manufacturing Firms Patent (Or Not)", NBER Working Paper $\mathrm{n}^{\circ} 7552$.

Dachs, B., Hanzl-Weiss, D., Kampik, F., Leitner, S., Scherngell, T., Stehrer, R., Urban, W., and Zahradnik, G., (2012), EUR 25505 - Internationalisation of business investments in $R \& D$ and analysis of their economic impact Luxembourg, Publications Office of the European Union.

de Rassenfosse, G., Dernis, H., Guellec, D., Picci, L., and van Pottelsberghe de la Potterie, B., (2013), "The worldwide count of priority patents: A new indicator of inventive activity", Research Policy, vol. 42, n 3, pp. 720-737.

de Rassenfosse, G., and van Pottelsberghe de la Potterie, B., (2009), "A policy insight into the R\&Dpatent relationship", Research Policy, vol. 38, n 5, pp. 779-792.

Dernis, H. and Khan, M., (2004), "Triadic patent families methodology", OECD STI working paper $n^{\circ} 2004 / 2$.

Doz, Y. L., Wilson, K., Veldhoen, S., Goldbrunner, T., and Altman, G., (2006), "Innovation: is global the way forward? A joint study by Booz Allen Hamilton and INSEAD”, INSEAD.

Dunning, J. H., (1997), "The economic theory of the firm as the basis for a 'core' theory of international production", in: I. Islam and W. Shepherd, (eds.), Current issues in international business, Cheltenham: Edward Elgar, pp. 60-68.

Dunning, J. H., and Lundan, S. M., (2009), "The internationalisation of corporate R\&D: a review of the evidence and some policy implications for home countries", Research Policy vol. 26, n 1-2, pp. 13-33.

Fisher III W. W. and Oberholzer-Gee, F., (2013), "Strategic Management of Intellectual Property: An Integrated Approach”, California Management Review, vol. 55, $\mathrm{n}^{\circ} 4$, pp. 157-183.

Florida, R. (1997), “The globalization of R\&D: results of a survey of foreign-affiliated R\&D laboratories in the USA", Research Policy, vol. 26, n 1, pp. 85-103.

Frost, T. S., (2001), "The geographic sources of foreign subsidiaries innovations", Strategic Management Journal, 22, $\mathrm{n}^{\circ}$ 2, pp. 101-123.

Gammeltoft, P., (2006), "Internationalisation of R\&D: trends, drivers and managerial challenges", International Journal of Technology and Globalisation, vol. 2, n 1-2, pp. 177-199.

Gassmann, O., Reepmeyer, G., and von Zedtwitz, M., (2008), Leading Pharmaceutical Innovation. Trends and Drivers for Growthin the Pharmaceutical Industry, $2^{\text {nd }}$ edition, Heidelberg: SpringerVerlag, Berlin.

Grimes, S. and Miozzo, M., (2015), "Big Pharma's internationalisation of R\&D to China", European Planning Studies, vol. 23, n 9, pp. 1873-1894.

Grupp, H. and Schmoch, U., (1999), "Patent statistics in the age of globalisation: new legal procedures, new analytical methods, new economic interpretation", Research Policy, vol. $28, \mathrm{n}^{\circ} 4$, pp. 377-396. 
Hu, A. G., (2010), "Propensity to patent, competition and China's foreign patenting surge", Research Policy, vol. 39, n 7, September, pp. 985-999.

Iammarino, S., and McCann, P., (2013), Multinationals and Economic Geography: Location, Technology and Innovation, Cheltenham: Edward Elgar Publishing Ltd.

Iwasa, T., and Odagiri, H., (2004), "Overseas R\&D, knowledge sourcing, and patenting: An empirical study of Japanese R\&D investment in the US", Research Policy, vol. 33, n ${ }^{\circ}$, pp. 807-828.

Jakovljevic, M. B., (2014), "The Key Role of the Leading Emerging Bric Markets in the Future of Global Health Care", Serbian Journal of Experimental and Clinical Research, vol 15, n 3, pp. 139-143.

Keupp, M. M. Friesike, S., and von Zedtwitz, M., (2012), "How do foreign firms patent in emerging economies with weak appropriability regimes? Archetypes and motives", Research Policy, vol. 41, $\mathrm{n}^{\circ} 8$, pp. 1422-1439.

Kuemmerle, W., (1997), "Building effective R\&D capabilities abroad", Harvard Business Review, vol. $75, \mathrm{n}^{\circ} 2$, pp. 61-70.

Kuemmerle, W., (1999), "The drivers of foreign direct investment into research and development: an empirical investigation", Journal of International Business, vol. 30, nº 1, pp. 1-24.

Kuemmerle, W., (1997), "Building effective R\&D capabilities abroad", Harvard Business Review, vol. $75, \mathrm{n}^{\circ} 2$, pp. 61-70.

Lall, S., (1979), "The international allocation of research activity by US multinationals", Oxford Bulletin of Economics and Statistics, vol. 41, n 4, pp. 313-331.

Lanjouw, J. O., Pakes, A., and Putnam, J., (1998), "How to Count Patents and Value Intellectual Property: The uses of patent renewal and application data", Journal of Industrial Economics, vol. $46, \mathrm{n}^{\circ}$ 4, pp. 405-432.

Laurens, P., Le Bas, C., Schoen, A., Villard, L., and Larédo, P., (2015a), "The rate and motives of the internationalisation of large firm R\&D (1994-2005): Toward a turning point?", Research Policy, vol. 44, n 3 , pp. 765-776.

Laurens, P., Le Bas, C., Schoen, A., and Larédo, P., (2015b), "Internationalisation of European MNCs R\&D: "deglobalisation" and evolution of the locational strategies", Management international, vol. $19, \mathrm{n}^{\circ} 4$, pp. 83-98.

Laurens, P., Villard, L., Schoen, A., Larédo, P., (2018), “The artificial patents in the PATSTAT database: How much do they matter when computing indicators of internationalisation based on worldwide priority patents?", Scientometrics, DOI: 10.1007/s11192-017-2578-5.

Le Bas, C., and Sierra, C., (2002), "Location versus home country advantages in R\&D activities: some further results on multinationals' locational strategies", Research Policy, vol. 31, $\mathrm{n}^{\circ} 4$, pp. 589-609.

Liu, M., and La Croix, S., (2015), "A cross-country index of intellectual property rights in pharmaceutical inventions", Research Policy, vol. 44, n 1, pp. 206-216.

Magazzini, L., Pammolli, F., and Riccaboni, M., (2004), "Dynamic competition in pharmaceuticals: Patent expiry, generic penetration, and industry structure", European Journal of Health Economics, Vol. 5, n², pp. 175-182.

Mahlich, J.C. (2010), "Patents and performance in the Japanese pharmaceutical industry: An institution-based view", Asia Pacific Journal of Management, vol. 27, n 1, pp. 99-113. 
Malerba, F., and Orsenigo, L., (2015), "The evolution of the pharmaceutical industry", Business History, vol. 57, $\mathrm{n}^{\circ}$ 5, pp. 664-687.

Maskus, K, (2000), Intellectual Property Rights in the Global Economy, Washington DC: Institute of International Economics.

Mazzucato, M., and Dosi, G., (2010), Knowledge accumulation and industry evolution: The case of Pharma-Biotech, Cambridge: Cambridge University Press.

Moncada-Paternò-Castello, P., Vivarelli, M., and Voigt, P., (2011), "Drivers and Impacts in the Globalisation of Corporate R\&D: An Introduction Based on the European Experience", Industrial and Corporate Change, vol. 20, $\mathrm{n}^{\circ} 1$, pp. 585-603.

Narula, R., and Guimón, J., (2010), "The investment development path in a globalised world: Implications for eastern Europe”, Eastern Journal of European Studies, vol. 1, n 2, pp. 5-19.

Narula, R., and Zanfei, A., (2005), "Globalisation of innovation: the role of multinational enterprises", in: J. Fagerberg, D. Mowery and R. R. Nelson, (eds.), The Oxford Handbook of Innovation, Oxford: Oxford University Press, pp. 318-345.

Neuhausler, P., and Frietsch, R., (2013), "Patent families as macro level patent value indicators: applying weights to account for market differences", Scientometrics, vol. 96, n 1, pp. 27-49.

Odagiri, H., and Yasuda, H., (1996), "The determinants of overseas R\&D by Japanese firms: an empirical study at the industry and company levels", Research Policy, vol. 25, n 7, pp. 10591079.

OECD, (2005), "Main Science and Technology Indicators", vol. 1.

Park, W. G., (2008), “International patent protection: 1960-2005”, Research Policy, vol. 37, n 4 , pp. 761-766.

Patel, P. and Pavitt, K., (1991), "Large firms in the production of the world's technology: an important case of 'Non-Globalisation"”, Journal of International Business Studies, vol. 22, ${ }^{\circ} 1$, pp. 1-21.

Patel, P. and Vega, M., (1999), "Patterns of internationalisation of corporate technology: location vs. home country advantages", Research Policy, vol. 28, n 2-3, pp. 145-155.

Piscitello, L., (2011), "Strategy, location, and the conceptual metamorphosis of the MNC", Global Strategy, vol. 1, n 1-2, pp. 127-131.

Rafols, I., Hopkins, M. M., Hoekman, J., Siepel, J., O'Hare, J., Perianes-Rodríguez, A., and Nightingale, P., (2014), «Big Pharma, little science? A bibliometric perspective on Big Pharma's R\&D decline », Technological Forecasting and Social Change, vol. 81, pp. 22-38.

Roberts, E. B., (2001), "Benchmarking global strategic management of technology", Research Technology Management, vol. 29, $\mathrm{n}^{\circ}$ 1, pp. 71-88.

Roijakkers, N. and Hagedoorn, J., (2006), "Inter-firm R\&D partnering in pharmaceutical biotechnology since 1975: Trends, patterns, and networks", Research Policy, vol. 35, $\mathrm{n}^{\circ} 3$, pp. 431-446.

Ronstadt, R. C., (1978), "International R\&D: the establishment and evolution of research and development abroad by seven US multinationals", Journal of International Business Studies, vol. $9, \mathrm{n}^{\circ} 1$, pp. 7-24.

Rugman, A. M., (1981), Inside the multinationals: The economics of internal markets, New York, Columbia University Press. 
Ryuhei, W. and Banri, I., (2007), "The Effects of Stronger Intellectual Property Rights on Technology Transfer: Evidence from Japanese Firm-level Data", KIER Working Papers $n^{\circ} 632$, Kyoto University, Institute of Economic Research.

Sachwald, F., (2008), "Location choice within global innovation networks: the case of Europe", Journal of Technology Transfer, vol. 33, $\mathrm{n}^{\circ}$ 4, pp. 364-378.

Saggi, K., (2002), "Trade, foreign direct investment, and international technology transfer: A survey", The World Bank Research Observer, vol. 17, n² 2, pp. 191-235.

Sternitzke, C., (2009), "Defining triadic patent families as a measure of technological strength", Scientometrics, vol. 81, n ${ }^{\circ}$, pp. 91-109.

UNCTAD, (2005), "World Invest Report: Transnational corporations and the internationalisation of R\&D", United Nations, New York and Geneva, (http: //unctad.org/en/docs/wir2005_en.pdf).

von Zedtwitz, M., and Gassmann, O., (2002), "Market versus technology drive in R\&D internationalisation: four different patterns of managing research and development", Research Policy, vol. 31, n 4, pp. 569-588.

WIPO, (2015), Breakthrough Innovation and Economic Growth, Economics and Statistics Series, Geneva.

1. That is to say triadic plus China and Korea.

2. Internationalisation in general equally plays a role. For example, according to Blind et al. (2003) pharmaceuticals are more internationally oriented - and, therefore, have a higher average number of family members - than for example machinery or automobiles.

3. The two strategies could be found in a single firm that can adopt different strategies according to the product.

4. In 2004, the first twelve pharmaceutical firms with the highest turnover were all located in western countries: Pfizer (USA), GlaxoSmithKline (G.B.), Sanofi-Aventis (France), Johnson \& Johnson (USA), Merck \& Co (USA), Novartis (Switzerland), AstraZeneca (G.B. I Sweden), Roche (Switzerland), Bristol-Myers Squibb (USA), Wyeth (USA), Abbott (USA), Lilly (USA). Some of them merged later, like Pfizer, which bought Wyeth in 2009.

5. The overall diffusion was quite limited: the mean number of countries in which a drug was launched was 22.4 (out of a possible 76). Only $39 \%$ of the drugs were launched in ten or fewer countries, and only $41 \%$ were launched in more than 25 countries.

6. Completion of information on artificial patents relies on the retrieval of information from the nearest completed patent in the Inpadoc patent family, which includes the artificial patent to be completed. The retrieved information includes the names and addresses of inventors and applicants, ICP classes and dodb family id (Laurens et al, 2017).

7. A simple patent family includes all patent applications that share the same active priorities. 
8. The reasons that have initiated the opening of Japanese drug firms to foreign markets could be the same as those that prevent the interest of foreign firms in the Japanese market.

9. Chan (2010) considers many countries. Our framework, based on triadic patenting, is a little different.

10. The value of the invention (or the invention quality) (Chan, 2010) plays an important role in firms' decisions to patent abroad. Unfortunately, a measure of patent value is missing in our paper. The problem, in fact, is the following. With respect to patent value we are not interested in the ex-post value but in the ex-ante one. The ex-post value is the value evidenced at the end of the patent life cycle which is strongly impacted by firm strategy in terms of firm presence in foreign markets and the localization of $\mathrm{R} \& \mathrm{D}$ activity. Therefore, it is impacted by the fact that the patent is becoming triadic or new triadic. It cannot be used as an independent variable that would explain the patent extension. A good measure of patent value should be calculated just after the application of the priority patent as an expected potential economic value of the patent. We do not have the means to calculate this. The patent citations scheme does not work here. We tried to put in the regressions the number of inventors related to each single invention (given in the patent document) as a proxy for the patent value. But we have never found any significant effect of this variable (the estimation results are not reported here)..

11. See Laurens et al. (2015a) for more details of the percentage of the regional and intercontinental internationalisation of patents.

12. Information related to drug approvals is not easily available for China and Korea in the period of time of interest.

13. When we use this variable in the models we discard from the model the patents applied by firms with no commercial activity at all in any country of the Triad. For these firms we consider that our indicator only centered on drugs to track their commercial activity is not appropriate.

14. It is possible that we have missed a late extension of priority patents applied for between 2003 and 2005 that was not included in the database version (Patstat 2011). However, our tests have shown that the shares of triadic or IP5 patents reach an asymptote three years after the year of priority patent filing. As an example, for a population of priority patents applied for in 2003 , the share of patents that are extended as triadic or IP5 patents is $13 \%$ in 2004, $17 \%$ in 2005 and 19\% in 2006, 2007, 2008 and 2009.

15. Year dummies related to application patent filing year do not change any estimated coefficient. 
16. In general, $R \& D$ intensity does not have any explanatory power in our regression, with the exception of Model 3, in which this variable has a negative, weakly statistically significant impact for triadic patenting only.

17. At this stage it is important to recall that very few Japanese firms are internationalised in terms of R\&D (see among others Le Bas and Sierra, 2002). 
Annex 1: Distribution of patents applied for by pharmaceutical firms across technological fields

\begin{tabular}{|l|c|c|c|}
\hline Technology field & All samples & US \& EU firms & JP firms \\
\hline Measurement & 0.03 & 0.04 & 0.01 \\
\hline Analysis of biological materials & 0.04 & 0.04 & 0.04 \\
\hline Medical technology & 0.14 & 0.17 & 0.01 \\
\hline Organic fine chemistry & 0.11 & 0.11 & 0.08 \\
\hline Biotechnology & 0.07 & 0.07 & 0.05 \\
\hline Pharmaceuticals & 0.47 & 0.42 & 0.69 \\
\hline Others & 0.15 & 0.16 & 0.11 \\
\hline Total & 1.00 & 1.00 & 1.00 \\
\hline
\end{tabular}


Annex 2 : Correlation tables between explanatory variables for US \& European firms and Japanese firms

\begin{tabular}{|c|c|c|c|c|c|c|c|c|c|c|c|c|}
\hline US \& EU firms & $\begin{array}{l}\text { firm_interc } \\
\text { ontinental } \\
\text { patent_pct }\end{array}$ & $\begin{array}{l}\text { firm_presen } \\
\text { ce_JP\&US\&E } \\
\text { U }\end{array}$ & $\begin{array}{l}\text { firm_presence } \\
\text { JP\&US\&EU\&K } \\
\text { R\&CN }\end{array}$ & $\begin{array}{l}\text { patent_ } \\
\text { JP_invt_ } \\
\text { pct }\end{array}$ & \begin{tabular}{|l|} 
patent__ \\
Asian_in \\
ventors \\
pct
\end{tabular} & \begin{tabular}{|l|} 
firm__ \\
log_nber \\
_priority \\
patent
\end{tabular} & $\begin{array}{l}\text { firm_R } \\
\& D \\
\text { intensi } \\
\text { ty }\end{array}$ & $\begin{array}{l}\text { firm_phar } \\
\text { maceutical } \\
\text { field_pate } \\
\text { nt_pct }\end{array}$ & $\mid \begin{array}{c}\text { firm_TS } \\
\text { _patent } \\
\text { ppct }\end{array}$ & $\left|\begin{array}{l}\text { firm_HB } \\
\text { E_patent } \\
\text { pct }\end{array}\right|$ & $\mid \begin{array}{l}\text { firm_HBA } \\
\text { _patent__ } \\
\text { pct }\end{array}$ & $\begin{array}{l}\text { firm_MS } \\
\text { _patent } \\
\text { _pct }\end{array}$ \\
\hline firm_intercontinental patent_pct & 1,00 & & & & & & & & & & & \\
\hline firm_presence_JP\&US\&EU & 0,21 & 1,00 & & & & & & & & & & \\
\hline firm_presence_JP\&US\&EU\&KR\&CN & 0,13 & 0,66 & 1,00 & & & & & & & & & \\
\hline patent_JP_invt_pct & $-0,28$ & $-0,16$ & $-0,41$ & 1,00 & & & & & & & & \\
\hline patent_Asian_inventors_pct & $-0,29$ & $-0,13$ & $-0,38$ & 0,97 & 1,00 & & & & & & & \\
\hline firm_log_nber_priority patent & 0,30 & 0,41 & 0,47 & $-0,13$ & $-0,07$ & 1,00 & & & & & & \\
\hline firm_R\&D intensity & $-0,09$ & $-0,32$ & $-0,21$ & $-0,06$ & $-0,07$ & $-0,34$ & 1,00 & & & & & \\
\hline firm_pharmaceutical_field_patent_pct & $-0,21$ & $-0,41$ & $-0,62$ & 0,38 & 0,40 & $-0,14$ & 0,18 & 1,00 & & & & \\
\hline firm_TS_patent_pct & $-0,14$ & 0,34 & 0,09 & 0,10 & 0,07 & $-0,05$ & $-0,14$ & $-0,44$ & 1,00 & & & \\
\hline firm_HBE_patent_pct & $-0,05$ & $-0,56$ & $-0,39$ & 0,25 & 0,22 & $-0,27$ & $-0,10$ & 0,11 & 0,02 & 1,00 & & \\
\hline firm_HBA_patent_pct & 0,14 & 0,26 & 0,24 & $-0,25$ & $-0,21$ & 0,22 & 0,17 & 0,21 & $-0,55$ & $-0,83$ & 1,00 & \\
\hline firm_MS_patent_pct & $-0,15$ & 0,30 & 0,31 & $-0,11$ & $-0,13$ & 0,24 & $-0,12$ & $-0,50$ & 0,16 & $-0,27$ & $-0,01$ & 1,00 \\
\hline
\end{tabular}

\begin{tabular}{|c|c|c|c|c|c|c|c|c|c|c|c|c|}
\hline Japanese firms & $\begin{array}{l}\text { firm_interc } \\
\text { ontinental } \\
\text { patent_pct }\end{array}$ & $\begin{array}{l}\text { firm_presen } \\
\text { ce_JP\&US\&E } \\
\text { U }\end{array}$ & $\begin{array}{l}\text { firm_presence } \\
\text { _JP\&US\&EU\&K } \\
\text { R\&CN }\end{array}$ & $\begin{array}{l}\text { patent_ } \\
\text { JP_invt_ } \\
\text { pct }\end{array}$ & \begin{tabular}{|l|} 
patent__ \\
Asian_in \\
ventors \\
pct
\end{tabular} & \begin{tabular}{|l|} 
firm__ \\
log_nber \\
_priority \\
patent
\end{tabular} & \begin{tabular}{|l|} 
firm_R \\
$\& D$ \\
intensi \\
ty \\
\end{tabular} & $\begin{array}{l}\text { firm_phar } \\
\text { maceutical } \\
\text { field_pate } \\
\text { nt_pct }\end{array}$ & $\left|\begin{array}{l}\text { firm_TS } \\
\text { _patent } \\
\text { ppct }\end{array}\right|$ & $\left|\begin{array}{l}\text { firm_HB } \\
\text { E_patent } \\
\text { pct }\end{array}\right|$ & $\begin{array}{l}\text { firm_HBA } \\
\text { ppatent_ } \\
\text { pct }\end{array}$ & $\begin{array}{l}\text { firm_MS } \\
\text { _patent } \\
\text { _pct }\end{array}$ \\
\hline firm_intercontinental patent_pct & 1,00 & & & & & & & & & & & \\
\hline firm_presence_JP\&US\&EU & 0,41 & 1,00 & & & & & & & & & & \\
\hline firm_presence_JP\&US\&EU\&KR\&CN & 0,84 & 0,40 & 1,00 & & & & & & & & & \\
\hline patent_JP_invt_pct & $-0,55$ & $-0,23$ & $-0,62$ & 1,00 & & & & & & & & \\
\hline patent_Asian_inventors_pct & $-0,45$ & $-0,18$ & $-0,49$ & 0,95 & 1,00 & & & & & & & \\
\hline firm_log_nber_priority patent & 0,71 & 0,48 & 0,90 & $-0,54$ & $-0,42$ & 1,00 & & & & & & \\
\hline firm_R\&D intensity & $-0,19$ & $-0,60$ & 0,18 & $-0,09$ & $-0,06$ & 0,09 & 1,00 & & & & & \\
\hline firm_pharmaceutical_field_patent_pct & 0,08 & $-0,31$ & 0,02 & $-0,03$ & $-0,04$ & $-0,11$ & 0,32 & 1,00 & & & & \\
\hline firm_TS_patent_pct & $-0,41$ & 0,30 & $-0,24$ & 0,17 & 0,15 & $-0,23$ & $-0,17$ & $-0,78$ & 1,00 & & & \\
\hline firm_HBE_patent_pct & $-0,72$ & $-0,70$ & $-0,43$ & 0,28 & 0,24 & $-0,34$ & 0,70 & 0,07 & 0,07 & 1,00 & & \\
\hline firm_HBA_patent_pct & 0,84 & 0,39 & 0,51 & $-0,34$ & $-0,29$ & 0,41 & $-0,45$ & 0,35 & $-0,60$ & $-0,84$ & 1,00 & \\
\hline firm MS patent_pct & $-0,20$ & 0,34 & $-0,28$ & 0,20 & 0,18 & $-0,05$ & $-0,17$ & 9 & $-0,21]$ & 6 & 0,25 & \\
\hline
\end{tabular}


Annex 3: Number and share of triadic patents in US \& Europe firms and Japanese firms according to the firm internationalisation rate.

\begin{tabular}{|c|c|c|c|c|c|c|c|c|c|c|c|c|c|c|}
\hline \multicolumn{2}{|c|}{$\begin{array}{l}\text { firm_intercontinental patent_pct (\%) } \\
\text { US \& EU firms }\end{array}$} & 0 & ]0-5] & ]5-10] & ]10-20] & ]20-30] & ]30-40] & ]40-50] & ]50-60] & ]60-70] & ]70-80] & ]80-90] & $90-100$ & Total \\
\hline \multirow{3}{*}{ Number of patents } & non triadic & 192 & 1337 & 627 & 1134 & 446 & 29 & 20 & 6 & 53 & 124 & 0 & 7 & 3975 \\
\hline & triadic & 12 & 61 & 15 & 244 & 373 & 3 & 0 & 0 & 3 & 2 & 0 & 0 & 713 \\
\hline & Total & 204 & 1398 & 642 & 1378 & 819 & 32 & 20 & 6 & 56 & 126 & 0 & 7 & 4688 \\
\hline \multirow{3}{*}{ Share of patents } & non triadic & 94,1 & 95,6 & 97,7 & 82,3 & 54,5 & 90,6 & 100,0 & 100,0 & 94,6 & 98,4 & - & 100,0 & \\
\hline & triadic & 5,9 & 4,4 & 2,3 & 17,7 & 45,5 & 9,4 & 0,0 & 0,0 & $\overline{5,4}$ & 1,6 & - & 0,0 & \\
\hline & Total & 100,0 & 100,0 & 100,0 & 100,0 & 100,0 & 100,0 & 100,0 & 100,0 & 100,0 & 100,0 & 100,0 & 100,0 & \\
\hline
\end{tabular}

\begin{tabular}{|l|l|r|r|r|r|r|}
\hline \multicolumn{2}{|l|}{$\begin{array}{l}\text { firm_intercontinental patent_pct (\%) } \\
\text { JP firms }\end{array}$} & 0 & $j 0-5]$ & $j 5-10]$ & $\begin{array}{c}\text { ]10- } \\
100]\end{array}$ & Total \\
\hline \multirow{3}{*}{ Number of patents } & non triadic & 23 & 128 & 148 & 0 & 299 \\
\cline { 2 - 7 } & triadic & 99 & 598 & 92 & 0 & 789 \\
\cline { 2 - 7 } & Total & 122 & 726 & 240 & 0 & 1088 \\
\hline \multirow{3}{*}{ Share of patents } & non triadic & 18,9 & 17,6 & 61,7 & - & \\
\cline { 2 - 6 } & triadic & 81,1 & 82,4 & 38,3 & - & \\
\cline { 2 - 6 } & Total & 100,0 & 100,0 & 100,0 & - & \\
\hline
\end{tabular}

Figure.1 Probability of triadic patents according to the rate of the firm R\&D overseas internationalisation (US \& European firms)

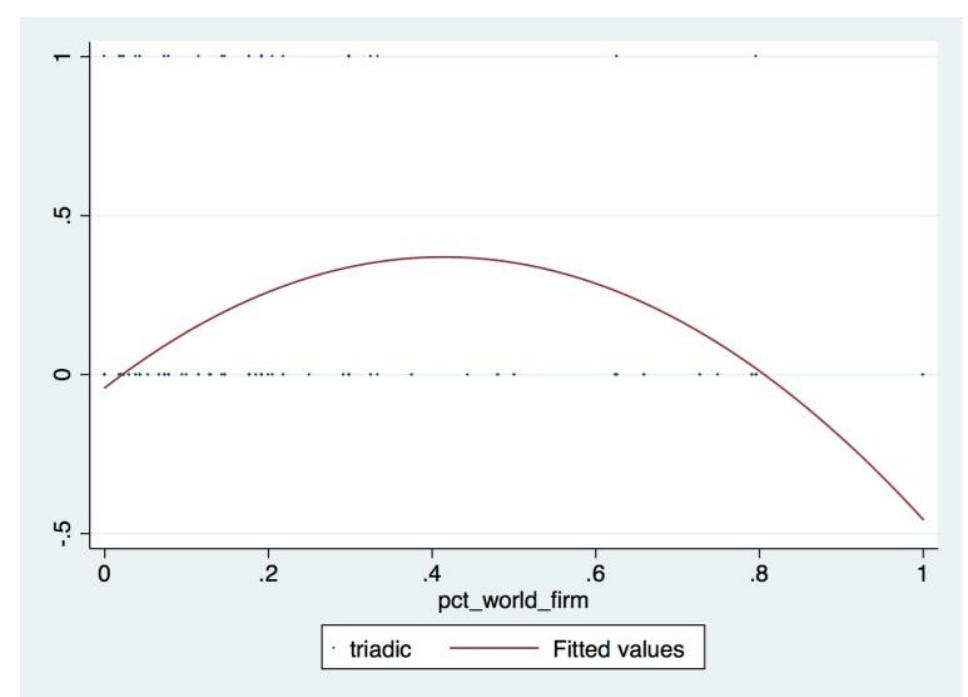


Compared to the variable firm_presence_JP\&US\&EU which does not give information on the type of activity the firm carries out in the country where she has set entities, the variable "firm_drug_triadic_market"is interesting. The later is restricted to the commercial activity of the firm (firms look for drug approval to sell them) while the former encompasses all types of firm's activity (commercial, manufacturing, $R \& D$, administrative entities, presence for fiscal reasons, ...) without any distinction.

However, built on drug approval by national or regional drug Agencies, this variable does not account for all the commercial activities of firms and is thus subject to doubt when the activities of the firm do not rely mainly on drugs. From Annex 1, we can consider that on average approximately 60\% (Pharmaceuticals, Biotechnologies and Fine Organic Chemistry) of the patent portfolios are related to drugs in US and European firms. We thus use this variable only for firms where the variable "firm_pharmaceutical field patent_pct" exceeds $10 \%$.

The "firm_drug_triadic_market" could not be used in the models built to test the explanatory power of our main variable firm_intercontinental patent_pct because of the correlation between the two variables (the correlation coefficient between firm_intercontinental patent_pct and firm_drug_triadic_market is 0.33 for US and European firms and 0.38 for Japanese firms). The "firm_drug_triadic_market" variable is also correlated to the variable accounting for the firm size: firm_log_nber_priority patent (correlation coefficients: 0.38 for the US and European firms and 0.35 for the Japanese firms). These correlations signal that the largest firms are the firms that already had a commercial activity in the 3 zones of the Triad. In addition, they evidence that the firms with an already internationalized market in the Triad show later a more internationalised R\&D activity.

However to test if a firm that has already developed commercial activities for drugs in each zone of the Triad will have a higher propensity to further apply for triadic patents, we run model 4 that takes into account the firm's presence in the Triad, using either the variable firm_local_presence JP\&US\&EU (already used in Model 3) or the variable firm_triadic_market. We have added the variables patent_JP_invt_pct, firm_R\&D intensity to stick to Model 3,pct_HBA and pct_HBE for convergence. Results of Model 4 are shown in Table A ; they could be compared with the results of Model 3 (Table B).

The results are the followings:

- the presence of a firm activity in the Triad has a positive and significant effect on the propensity to apply for triadic patents. This holds true using either firm_local_presence JP\&US\&EU or the firm_triadic_market. The two variables are very significant and their coefficient are very similar. This confirms Hypothesis 2. 
- Adding firm_triadic_market as an explanatory variable in Model 4 allows to raise the pseudo R2 value from 0.12 to 0.19 . This variable has thus a limited capacity to explain the probability to apply for triadic patent.

- The best Model in order to explain the probability to apply for triadic patent remains Model 3 (psuedo R2 = 0.26)

From this study of the use of variable "firm_triadic_market", we conclude that it consolidates our previous results obtained with the variable "local_presence JP\&US\&EU" to confirm Hypothesis 2. However this new variable did not bring any further advantage. In particular it did not increase very significantly the explanatory power of our models. This could be attributed to the fact that it only partially covers a market activity of the firms as it is based on only on drugs. Similar conclusions can be drawn when using the variable "firm_triadic_market" in the model to explain the probability to apply for Triad patents in Japanese firms.

Table A

\begin{tabular}{|c|c|c|c|}
\hline US \& EU firms & \multicolumn{3}{|c|}{ Model 4} \\
\hline Explanatory variables & \multicolumn{3}{|c|}{ Triadic } \\
\hline firm_triadic_market & $1.60(4.02)^{* * *}$ & & $1.70(3.38)^{* * *}$ \\
\hline firm_local_presence JP\&US\&EU & & & $3.04(5.62)^{* * *}$ \\
\hline patent_JP_invt_pct & $3.57(9.30)^{* * *}$ & $\begin{array}{c}3.71 \\
(10.02)^{* * *}\end{array}$ & $-0.06(0.31)$ \\
\hline firm_R\&Dintensity & $-0.01(0.32)$ & $-0.01(0.30)$ & \\
\hline pct_HBA & $-4.45(1.56)$ & $-3.96(1.57)$ & \\
\hline pct_HBE & $-8.26(2.65)^{*}$ & $-8.21(2.29)^{*}$ & \\
\hline const & $1.14(0.59)$ & $2.19(0.32)$ & 4422 \\
\hline Nber of data & 4422 & 4422 & 0.12 \\
\hline pseudo R2 & 0,19 & 0.15 & \\
\hline
\end{tabular}

Table B

\begin{tabular}{|c|c|}
\hline US \& EU firms & Model 3 \\
\hline Explanatory variables & Triadic \\
\hline firm_intercontinental patent_pct & $18.6(5.75)^{* * *}$ \\
\hline firm_intercontinental patent_pct2 & $-23.3(9.30)^{* * *}$ \\
\hline firm_local_presence JP\&US\&EU & $1.40(4.87)^{* * *}$ \\
\hline patent_JP_invt_pct & $3.09(8.89)^{* * *}$ \\
\hline firm_R\&D intensity & $-0.01(0.28)$ \\
\hline const & $-5.17(6.20)^{* * *}$ \\
\hline Nber of data & 4422 \\
\hline pseudo R2 & 0,26 \\
\hline
\end{tabular}


Table 1: Number of firms and patent families for priority patents and transnational priority patents

\begin{tabular}{|l|c|c|c|}
\hline $\begin{array}{l}\text { Pharma and } \\
\text { biotech }\end{array}$ & $\begin{array}{c}\text { Number of } \\
\text { firms }\end{array}$ & $\begin{array}{c}\text { Number of transnational } \\
\text { priority patents }\end{array}$ & $\begin{array}{c}\text { Number of priority } \\
\text { patents }\end{array}$ \\
\hline US firms & 30 & 1161 & 4649 \\
\hline EU firms & 31 & 3527 & 7571 \\
\hline JP firms & 15 & 1088 & 5413 \\
\hline Total & 76 & 5776 & 17633 \\
\hline
\end{tabular}


Table 2: Share of patents with IP protection in the different countries or zones.

\begin{tabular}{|l|l|l|l|}
\hline \multicolumn{1}{|c|}{ IP coverage } & All firms & US \& EU firms & JP firms \\
\hline Europe (EP patents) & 0.89 & 0.90 & 0.89 \\
\hline US & 0.82 & 0.81 & 0.87 \\
\hline Japan & 0.29 & 0.17 & 0.85 \\
\hline Korea & 0.35 & 0.32 & 0.36 \\
\hline China & 0.43 & 0.47 & 0.35 \\
\hline Europe + US & 0.76 & 0.75 & 0.81 \\
\hline Triadic & 0.25 & 0.15 & 0.72 \\
\hline New triadic & 0.08 & 0.04 & 0.23 \\
\hline Number of patents & 5776 & 4688 & 1088 \\
\hline
\end{tabular}


Table 3: Overview of the explanatory variable: definition, type and statistics

\begin{tabular}{|c|c|c|c|c|c|c|}
\hline \multirow{2}{*}{ Explanatory variables } & \multirow{2}{*}{ Definition } & \multirow{2}{*}{ Type } & \multicolumn{2}{|c|}{ US \& European firms } & \multicolumn{2}{|c|}{ Japanese firms } \\
\hline & & & Mean & Std. Err. & Mean & Std. Err. \\
\hline $\begin{array}{l}\text { firm_intercontinental } \\
\text { patent_pct }\end{array}$ & $\begin{array}{l}\text { share of patents invented } \\
\text { overseas }\end{array}$ & $\begin{array}{l}\text { Continuous } \\
\text { quantitative }\end{array}$ & 0.16 & 0.002 & 0.03 & 0.001 \\
\hline firm_presence JP\&US\&EU & $\begin{array}{l}\text { presence of firm's entities } \\
\text { in Japan, the US, and one } \\
\text { EU country }\end{array}$ & qualitative & 0.84 & 0.005 & 0.26 & 0.013 \\
\hline $\begin{array}{l}\text { firm_presence } \\
\text { JP\&US\&EU\&KR\&CN }\end{array}$ & $\begin{array}{l}\text { presence of firm's entities } \\
\text { in Japan, the US, an EU } \\
\text { country, China and Korea }\end{array}$ & qualitative & 0.71 & 0.007 & 0.13 & 0.091 \\
\hline patent_JP_invt_pct & $\begin{array}{l}\text { share of inventors located } \\
\text { in Japan }\end{array}$ & $\begin{array}{l}\text { Continuous } \\
\text { quantitative }\end{array}$ & 0.03 & 0 & 0.92 & 0.01 \\
\hline patent_Asian_inventors_pct & $\begin{array}{l}\text { share of inventors located } \\
\text { in Asia }\end{array}$ & $\begin{array}{l}\text { Continuous } \\
\text { quantitative }\end{array}$ & 0.04 & 0 & 0.98 & 0.01 \\
\hline nber_priority patent & $\begin{array}{l}\text { number of firm's priority } \\
\text { patents }\end{array}$ & $\begin{array}{l}\text { Continuous } \\
\text { quantitative }\end{array}$ & 197.39 & 43.77 & 360.87 & 165.55 \\
\hline $\begin{array}{l}\text { firm_pharmaceutical field } \\
\text { patent_pct }\end{array}$ & $\begin{array}{l}\text { share of patents in the } \\
\text { pharmaceuticals techno } \\
\text { field }\end{array}$ & $\begin{array}{l}\text { Continuous } \\
\text { quantitative }\end{array}$ & 0.42 & 0 & 0.74 & 0 \\
\hline firm_R\&D intensity & $\begin{array}{l}\text { R\&D investments over } \\
\text { sales }\end{array}$ & $\begin{array}{l}\text { Continuous } \\
\text { quantitative }\end{array}$ & 23.28 & 2.22 & 16.59 & 0.13 \\
\hline firm_TS_patent_pct & \begin{tabular}{|l|} 
share of patents following \\
a Technology Seeking \\
Strategy
\end{tabular} & $\begin{array}{l}\text { Continuous } \\
\text { quantitative }\end{array}$ & 0.05 & 0.02 & 0.07 & 0.07 \\
\hline firm_HBE_patent_pct & $\begin{array}{l}\text { share of patents following } \\
\text { a Home Base Exploiting } \\
\text { Strategy }\end{array}$ & $\begin{array}{l}\text { Continuous } \\
\text { quantitative }\end{array}$ & 0.26 & 0.04 & 0.18 & 0.11 \\
\hline firm_HBA_patent_pct & $\begin{array}{l}\text { share of patents following } \\
\text { a Home Base Augmenting } \\
\text { Strategy }\end{array}$ & $\begin{array}{l}\text { Continuous } \\
\text { quantitative }\end{array}$ & 0.68 & 0.04 & 0.74 & 0.12 \\
\hline firm_MS_patent_pct & $\begin{array}{l}\text { share of patents following } \\
\text { a Market Seeking strategy }\end{array}$ & $\begin{array}{l}\text { Continuous } \\
\text { quantitative }\end{array}$ & 0.01 & 0 & 0.01 & 0.01 \\
\hline
\end{tabular}


Table 4: Determinants of triadic and new triadic IP protection in patent portfolios for US \& Europe pharmaceuticals firms.

\begin{tabular}{|c|c|c|c|c|c|c|c|c|c|c|c|c|}
\hline \multirow{3}{*}{\begin{tabular}{|l} 
US \& EU firms \\
$\begin{array}{l}\text { Explanatory } \\
\text { variables }\end{array}$
\end{tabular}} & \multicolumn{4}{|c|}{ Model 1} & \multicolumn{4}{|c|}{ Model 2} & \multicolumn{4}{|c|}{ Model 3} \\
\hline & \multicolumn{2}{|c|}{ Triadic } & \multicolumn{2}{|c|}{ New triadic } & \multicolumn{2}{|c|}{ Triadic } & \multicolumn{2}{|c|}{ New triadic } & \multicolumn{2}{|c|}{ Triadic } & \multicolumn{2}{|c|}{ New triadic } \\
\hline & linear & quadratic & linear & quadratic & linear & quadratic & linear & quadratic & linear & quadratic & linear & quadratic \\
\hline $\begin{array}{c}\text { firm_intercontinent } \\
\text { al patent_pct }\end{array}$ & $2.07(1.67)$ & $12.12(10.05)^{* * *}$ & * $0.68(0.99)$ & $6.7(4.53)^{* * *}$ & $2.83(1.92)^{*}$ & $17.04(5.05)^{* * *}$ & $1.8(2.00)^{*}$ & $12.60(4.40)^{* * *}$ & $2.86(1.61)$ & $15.70(4.28)^{* * *}$ & $2.02(2.17)^{*}$ & $13.40(3.71)^{* * *}$ \\
\hline $\begin{array}{c}\text { firm_intercontinent } \\
\text { al patent_pct2 }\end{array}$ & & $\left|-16.28(6.83)^{* * *}\right|$ & & $-12.10(3.56)^{* * *}$ & & $-25.48(3.46)^{* * *}$ & & $-22.03(3.81)^{* * *}$ & & $-19.58(3.54)^{* * *}$ & & $-17.80(3.82)^{* * *}$ \\
\hline $\begin{array}{c}\text { firm_local_presence } \\
\text { JP\&US\&EU }\end{array}$ & & & & & & & & & $1.58(2.41)^{*}$ & $0.49(0.77)^{* * *}$ & $1.74(2.92)^{* *}$ & $1.14(3.59)^{* * *}$ \\
\hline patent_JP_invt_pct & & & & & & & & & $1.34(3.58)^{* * *}$ & $3.10(7.81)^{* * *}$ & $2.03(6.38)^{* * *}$ & $1.75(6.06)^{* * * *}$ \\
\hline $\begin{array}{c}\text { patent_Asian } \\
\text { inventors_pct }\end{array}$ & & & & & $5.56(3.02)^{* *}$ & $5.47(5.91)^{* * *}$ & $3.28(2.55)^{*}$ & $4.54(1.89)^{*}$ & & & & \\
\hline $\begin{array}{l}\text { firm_log_nber } \\
\text { priority patent }\end{array}$ & $0.98(3.37)^{* * *}$ & $0.55(2.77)^{* *}$ & $\left|1.22(5.34)^{* * *}\right|$ & $0.89(3.27)^{* * *}$ & & & & & & & & \\
\hline firm_R\&D intensity & $-0.00(2.03)^{*}$ & $0.00(0.67)$ & $-0.00(0.46)$ & $-0.00(1.39)$ & & & & & $-0.00(2.96)^{* *}$ & $0.00(1.62)$ & $-0.08(0.70)$ & $-0.03(0.41)$ \\
\hline $\begin{array}{c}\text { firm_pharmaceutica } \\
\text { I field patent_pct } \\
\end{array}$ & $-2.88(4.23)^{* * *} \mid$ & $\left|-2.82(4.67)^{* * *}\right|$ & $-1.81(3.32)^{* *} \mid$ & $-1.75(3.12)^{* *}$ & & & & & & & & \\
\hline firm_TS_patent_pct & & & & & $10.41(4.94)^{* * *}$ & $6.34(3.64)^{* * *}$ & $8.14(4.37)^{* * *}$ & $5.88(2.76)^{* *}$ & & & & \\
\hline $\begin{array}{c}\text { firm_MS_patent_ } \\
\text { pct }\end{array}$ & & & & & $189(0.89)$ & $2.52(1.59)$ & $1.76(0.92)$ & $2.31(1.24)$ & & & & \\
\hline const & $10.95(4.54)^{* * *}$ & $-6.08(4.17)^{* * *}$ & $10.95(6.51)^{* * *}$ & $-9.22(4.78)^{* * *}$ & $-3.99(6.70)^{* * *}$ & $-4.87(10.61)^{* * *}$ & $-4.80(10.35)^{* * *}$ & \begin{tabular}{|l|}
$-5.52(9.06)^{* * * *}$ \\
\end{tabular} & $2.97(1.60)^{* * * *}$ & $5.10(7.76)^{* * *}$ & $-4.0(3.07)^{* * *}$ & $-5.37(4.07)^{* * *}$ \\
\hline Nber of data & & 4688 & 4688 & 4688 & 4688 & 4535 & 4535 & 4535 & 4688 & 4688 & 4688 & 4688 \\
\hline pseudo R2 & 0,19 & 0.22 & 0,11 & 0,12 & 0.16 & 0.22 & 0.075 & 0,1 & 0.19 & 0.26 & 0.08 & 0.13 \\
\hline
\end{tabular}

$* * *: 0.1 \%, * *:<1 \%, *:<5 \%$. t statistics into brackets 
Table 5: Determinants of triadic and new triadic IP protection in patent portfolios of Japanese pharmaceutical firms.

\begin{tabular}{|c|c|c|c|c|c|c|}
\hline \multirow{3}{*}{ Explanatory variables } & \multicolumn{4}{|c|}{ Model 1a } & \multicolumn{2}{|c|}{ Model 2a } \\
\hline & \multicolumn{2}{|c|}{ Triadic } & \multicolumn{2}{|c|}{ New triadic } & \multirow[t]{2}{*}{ Triadic } & \multirow[t]{2}{*}{ New triadic } \\
\hline & linear & quadratic & linear & quadratic & & \\
\hline firm_intercontinental patent_pct & $-32.78(3.83)^{* * *}$ & $33.66(1.33)$ & $6.56(1.41)$ & $24.51(0.90)$ & & \\
\hline firm_intercontinental patent_pct2 & & $-1174(2.92)^{* *}$ & & $-293(0.65)$ & & \\
\hline firm_presence JP\&US\&EU & & & & & $-0.16(0.64)$ & $0.95(3.20)^{* * *}$ \\
\hline patent JP_inventor's share & & & & & $4.03(4.18)^{* * *}$ & $2.20(2.17)^{*}$ \\
\hline firm_R\&D intensity & $-0.06(1.52)$ & $-0.05(1.69)$ & $-0.09(5.90)^{* * *}$ & $-0.90(5.61)^{* * *}$ & & \\
\hline firm_pharmaceutical patent_pct & $3.30(2.89)^{* *}$ & $2.41(2.74)^{* *}$ & $0.84(0.48)$ & $0.71(0.54)$ & $2.59(3.10)^{* *}$ & $0.65(0.46)$ \\
\hline const & $1.81(1.35)$ & $0.72(0.56)$ & $-0.57(0.64)$ & $-0.60(0.68)$ & $-4.21(3.52)^{* * *}$ & $-3.89(2.56)^{* *}$ \\
\hline Nber of data & 1088 & 1088 & 1088 & 1088 & 1088 & 1088 \\
\hline pseudo R2 & 0,13 & 0,14 & 0,028 & 0,028 & 0.30 & 0.07 \\
\hline
\end{tabular}

$* * *: 0,1 \%, * *:<1 \%, *:<5 \%, \mathrm{t}$ statistics into brackets 